\title{
SOME PHYTOSEIIDAE (ACARINA: MESOSTIGMATA) FROM MADAGASCAR, WITH DESCRIPTIONS OF EIGHT NEW SPECIES AND NOTES ON THEIR BIOLOGY
}

\author{
by \\ LEO BLOMMERS \\ Laboratory of Experimental Entomology, University of Amsterdam, The Netherlands ${ }^{1}$ )
}

\begin{abstract}
The taxonomic portion of this paper discusses 27 species of mites of the family Phytoseiidae known to occur on plants in Madagascar.

Eight new species are described: Phytoseius (Phytoseius) betsiboka. Ph. (Pennaseius) onilahy, Amblyseius (Amblyseius) hova A. (A.) ankaratrae, A. (A.) boina, A. (A.) sakalava, A. (A.) trichophilus and $A$. (Proprioseiopsis) tulearensis.

The following species are recorded for the first time from the island: Typhlodromus (Typhloseiopsis) contiguus Chant, 1959, Phytoseius (Phytoseius) crinitus Swirski \& Shechter, 1961, Ph. (Ph.) intermedius Evans \& Macfarlane, 1961, Ph. (Pennaseius) hongkongensis Swirski \& Shechter, 1961, Ph. (P.) amba Pritchard \& Baker, 1962, Iphiseius (Iphiseius) degenerans (Berlese, 1889), I. (Trochoseius) gongylus Pritchard \& Baker, 1962, Paraphytoseius multidentatus Swirski \& Shechter, 1961, Amblyseius (Amblyseius) hima Pritchard \& Baker, 1962, A. (A.) deleoni Muma \& Denmark, 1970, A. (Proprioseiopsis) sundi Pritchard \& Baker, 1962 and $A$. (P.) peltatus Van der Merwe, 1968. Additional descriptions are given for most of these species. The male of $\boldsymbol{P}$. multidentatus is described for the first time.

New distribution records are presented for the following species: Typhlodromus scytinus Chazeau, 1970, the T. (Anthoseius) gutierrezi-chazeaui group, Amblyseius (Amblyseius) masiaka Blommers \& Chazeau, 1974, A. (A.) bibens Blommers, 1973, A. (A.) rotundus Blommers, 1973, A. (A.) brevipes Blommers, 1973 and $A$. (A.) tamatavensis Blommers, 1974.

The simultaneous occurrence of spider mites and other small arthropods on the plants on which the phytoseiids were collected is noted.

A final chapter summarizes the results of experiments devised to see whether the collected phytoseiid mites can be effectively predators of spider mites, i.e. of Tetranychus neocaledonicus André, 1933 and sometimes Oligonychus coffeae

1) Author's present address: Laboratory of Parasitology, University of Leiden, Rapenburg 33, Leiden, The Netherlands.
\end{abstract}

(Nietner, 1861). Most of these results were negative. Only, Typhlodromus contiguus, Amblyseius tulearensis and A. sundi can regulate population numbers of the first prey species under circumstances of low webbing and/or additional food. Iphiseius degenerans, and possibly Amblyseius rotundus, can control Oligonychus coffeae in their area of distribution.

\section{INTRODUCTION}

Phytoseiid mites rank among the most important natural enemies of phytophagous mites and therefore have received increasing attention during the last decennia. The number of described species has grown from less than 20 in 1951 (Nesbitt), to around 1000 at the moment.

This paper is the last in a series comprising an inventory of phytoseiid mites as predators of spider mites (Tetranychidae) conducted between 1970 and 1973 in Madagascar.

\section{SYSTEMATICS}

\section{Material and methods}

All phytoseiid mites were collected on plants by R. Blommers-Schlösser and the present author unless stated otherwise. The specimens were preserved in 70 per cent alcohol, cleared in 50 per cent lactic acid and mounted in Marc André's medium.

As the knowledge of natural relationships within the Phytoseiidae is still inconclusive, I have chosen a rather conservative generic and subgeneric division, which agrees in general with 
the one used by Van der Merwe (1968). The following are exceptions. According to its revised definition (Muma \& Denmark, 1968), the subgenus Proprioseiopsis Muma, 1961, of Amblyseius should contain also those species in which dorsal setae J2 are absent, and Phytoseius Ribaga, 1904, and Paraphytoseius Swirski \& Shechter, 1961, should be raised to generic rank.

The nomenclature of the dorsal setae is that proposed by Lindquist \& Evans (1965) and adapted for Phytoseiidae by Athias-Henriot (1966) (cf. Blommers \& Chazeau (1974) and fig. 1). Dimensions are given in micrometers. The author's collection numbers accompany the collection data.

Spider mites collected concurrently with the phytoseiid mites have been identified by Dr. J. Gutierrez, and are mentioned eventually together with other small arthropods. The entire collection of Malagasy Phytoseiidae is deposited in the Institute of Taxonomic Zoology (Zoölogisch Museum) of the University of Amsterdam.

\section{Descriptions}

\section{Typhlodromus scytinus}

Chazeau, 1970

Typhlodromus scytinus Chazeau, 1970: 3, figs. 1-7.

Material. - Two $\$$ \& (T 18 series) collected on grapevine (Vitis vinifera), 1. III. 1972 at Tananarive-Ambodrona.

\section{Typhlodromus (Anthoseius) gutierrezi}

Blommers, 1973

Typhlodromus (Anthoseius) gutierrezi Blommers, 1973: 109, figs. 1-7.

Material. - Four $q \propto$ and one $\delta$ (64 series) from Euphorbia hirta, 9.111.1971: one $\$$ (63.3) from Abelmoschus esculentus (Malvaceae) and two $\$ \$$ (54 series) from Corchorus trilocularis (Tiliaceae), both 26.III.1971; one $\%$ (65.10) also from $C$. trilocularis, 2.IV.1971; all these specimens collected in the city of Tulear.

\section{Typhlodromus (Anthoseius) chazeaui}

\section{Blommers, 1973}

Typhlodromus (Anthoseius) chazeaui Blommers, 1973: 110, figs. 8-11.

Material. - Two $\$ \%$ (B 39 series) from Solanum sp., 21.V.1971 at Ifaty, in sea dunes $10 \mathrm{~km} \mathrm{~N}$. of Tuléar.

$T$. gutierrezi and $T$. chazeaui are intimately re- lated, and appear to form part of a more extensive species group. Both species were described from the region of Tuléar, where it is easy to distinguish them.

$T$. gutierrezi seems to be restricted to the more humid biotopes in the direct neighbourhood of Tuléar city, while $T$. chazeaui is a form of the sea dunes with sclerophyllous vegetation.

Our material from Majunga province, however, contains forms which we are unable to identify for the moment. They show, in various degrees of mixing, features which are not only proper to both aforementioned species but also to South African $T$. paganus Van der Merwe, 1968, and T. vescus Van der Merwe, 1968. More material is needed to understand the species complex.

The following specimens belong to this complex: $1 q$ and $1 \delta$ (M 1 series) on a species of Asclepiadaceae, 3 우 (M 3 series) and $2 \%$ (M 14 series) on unknown plants, $1 \%$ and 1 o (M 7 series) on Rhopalocarpus lucidus (Rhopalocarpaceae), 3 \% 9 (M 9 series) on Bauduinia sp. (Caesalpinaceae), 1 o (M 13.1) on Flacourtia ramontschi (Flacourtiaceae), $25 q q$ and 2 o $\delta$ (M 16 series) on Diospyros sp. (Ebenaceae), all from sand dunes near Katsepy (Majunga), 26.IV.1972. Further, 3 \% (M 6 series) on Ricinus communis (Euphorbiaceae), 1 (M 15.9) on Leonotis nepetaefolia (Labiatae), 2 \% (M 17 series) on Carica papaya (Caricaceae) at Ampijoroa (Majunga province), 24.IV.1972. In the same locality, $5 q \%$ and $2 \delta \delta$ (M 33 series) also on $R$. communis and $1 \delta$ (M 34.4) on Leptadenia madagascariensis (Asclepiadaceae), 30.XI.1972. One $\delta$ (M 12.5) on Pueraria javanica (Papilionaceae) at Ambato Boeni, 24.IV.1972; in the same place, $17 \%$ and 4 of (M 26 series) on Alchornea sp. (Euphorbiaceae), 12.IX.1972.

Typhlodromus (Typhloseiopsis) contiguus

Chant, 1959

Typhlodromus (Typhlodromus) contiguus Chant, 1959a: 29, figs. 1-6; Chant, 1959b: 50, figs. 303-304.

Typhlodromus (Typhloseiopsis) contiguus; Ehara, 1967: 71, figs. 12-16.

Material. - Four $\$ \%$ and four $\delta \delta$ (M 22-3k series) from a rearing starting with specimens found on several plants (Phaseolus sp., Papilionaceae; Leonotis sp., Labiatae and Ipomoea sp., Convolvulaceae) near homestead gardens in coastal forest, a few miles S. of Katsepy (Bombetoka Bay, opposite Majunga), 27.IV.1972.

Diagnosis. - Our specimens agree well with the available descriptions of this highly characteristic Typhlodromus species. Some dimensions in the female are slightly different: length dorsal shield $310, j 125$, j3 45, Z1 89, Z4 96, Z5 160, s3 70, s4 80, 
VL1 71, macrosetae genu, tibia and basitarsus IV of the same length: about 60 .

\section{Phytoseius (Phytoseius) crinitus}

Swirski \& Shechter, 1961

Phytoseius (Dubininellus) crinitus Swirski \& Shechter, 1961: 102, figs. 8-10 ( $\%)$; Swirski \& Amitai, 1966: 11, figs. 1-3 (ठ) ; Denmark, 1966: 66, fig. 27.

Phytoseius (Phytoseius) crinitus; Ehara \& Lee, 1971: 71, figs. 38-41.

Material. - Ten $\$ \circ$ (series T 19) were collected from grapevine (Vitis vinifera; Vitaceae) at Soavina, Miantso, Tananarive province, altitude about $1300 \mathrm{~m}$, on 8.Il.1972; one \& (T 10A.4) from lemon (Citrus limon; Rutaceae) in Tananarive-Nanisana, altitude $1250 \mathrm{~m}, 21 . \mathrm{IX} .1971$. Two $\$$ ㅇ (A 23.3 and A 42.3) were collected from Psidium guayava (Myrtaceae), the first at Ivoloina, Tamatave, on 25.VII.1972, the second in the city of Tamatave, 5.VIII.1972.

Discussion. - The specimens from Soavina and Ivoloina agree exceptionally well with the original description of $P$. crinitus. A 42.3 \% approaches Phytoseius ferox Pritchard \& Baker, 1962 , in having seta $s 3$ shorter and macroseta genu IV longer; dorsal setae $\mathrm{s} 4$ and $\mathrm{Z4}$ are not divided in this specimen.

\section{Phytoseius (Phytoseius) intermedius}

Evans \& Macfarlane, 1961

Phytoseius (Dubininellus) intermedius Evans \& Macfarlane, 1961: 587, figs. 1-3; Denmark, 1966: 70, fig. 29.

Phytoseius (Phytoseius) intermedius; Ehara, 1972: 170, figs. 122-125.

Phytoseius (Phytoseius) yira Pritchard \& Baker, 1962: 227, figs. 13-14.

Material. - Six $९ \%$ (A 26 series) from guava (Psidium guayava; Myrtaceae) in Tamatave City, 28.VII.1972.

Diagnosis. - The Malagasy specimens agree well with the descriptions of this species already given.

Field note. - This phytoseiid was accompanied by a not yet described spider mite of the genus Oligonychus Berlese, 1886.

Phytoseius (Phytoseius) betsiboka sp. $\mathrm{n}$.

Material. - Holotype $q$ (serial no. $M$ 30k.2) and seven paratypes (M 30k series: $3 \% q$ and $4 \sigma^{\circ}$ ) from a mass rearing started with specimens collected on Urena lobata (Malvaceae) along Route Nationale 4, km 491, near Amboromalandy, 11.IX.1972. Three paratypes (2 $\%$ and $1 \delta ; M$ 28 series) from Combretum villosum (Combretaceac) on the same spot and the same date as the holotype.

Differential diagnosis. - The pattern of the dorsal setae, R1 being absent, places this species within the subgenus Phytoseius Ribaga, 1904. Only a few species within this genus possess a single pair of pre-anal setae on the ventri-anal shield. $P$. betsiboka differs from them in the extreme length of seta $s 4$ which is considerably longer than any other dorsal seta. The presence of a large notocephalic pore caudad of seta $\mathrm{z} 5$ is unique among known species of this subgenus, but is found in a great majority of species in the subgenus Pennaseius Pritchard \& Baker, 1962.

\section{Description. -}

Female: Dorsal shield smooth, 280 long and 140 wide; incised near seta $r 2$; with at least ten pairs of pores, two of them large and surrounded by a distinct rim; fifteen pairs of setae on the shield; the longer thickened, with rows of spines along their length; their length: j1 30, j3 57, Z1 86, Z4 $98, \mathrm{Z5} \mathrm{114,} \mathrm{s3} \mathrm{23,} \mathrm{s4} \mathrm{166,} \mathrm{r2} \mathrm{54;} \mathrm{the} \mathrm{remaining}$ setae $(\mathrm{j} 4, \mathrm{j} 5, \mathrm{j} 6, \mathrm{~J} 5, \mathrm{z4}, \mathrm{z5}, \mathrm{s} 2)$ smooth and minute, less than 7 long. Peritremes reach nearly in front of setae $\mathrm{jl}$.

Sternal shield not well visible, poorly sclerotized. Genital shield as usual, 75 wide. Ventri-anal shield 93 long and 46 wide, without pores and with a single pair of pre-anals. Surrounding membrane with six pairs of pores, two pairs of metapodal platelets, and five pairs of setae; VL1 thickened and serrate, 78 long.

Leg IV with four blunt macrosetae: on both genu and tibia 18 long, on basitarsus 40 , distitarsus 42. Some other setae might be blunt too. Remaining legs without distinct macrosetae. Length tarsus IV (including basitarsus) 196.

Both digits of chelicera about 23 long. Fixed digit with four teeth, arranged as figured; movable digit with one tooth.

Spermatheca as figured. Major duct 29 long; cervix containing spermatophore 46 long.

Male: Dorsal shield 240 long and 130 wide. Arrangement of pores as in the female. Length of the large serrate setae: $\mathrm{j} 123, \mathrm{j} 348, \mathrm{Z1} \mathrm{59,} \mathrm{Z4} \mathrm{68,}$ Z5 61 , s3 21, s4 132, r2 40. Remaining setae minute. 


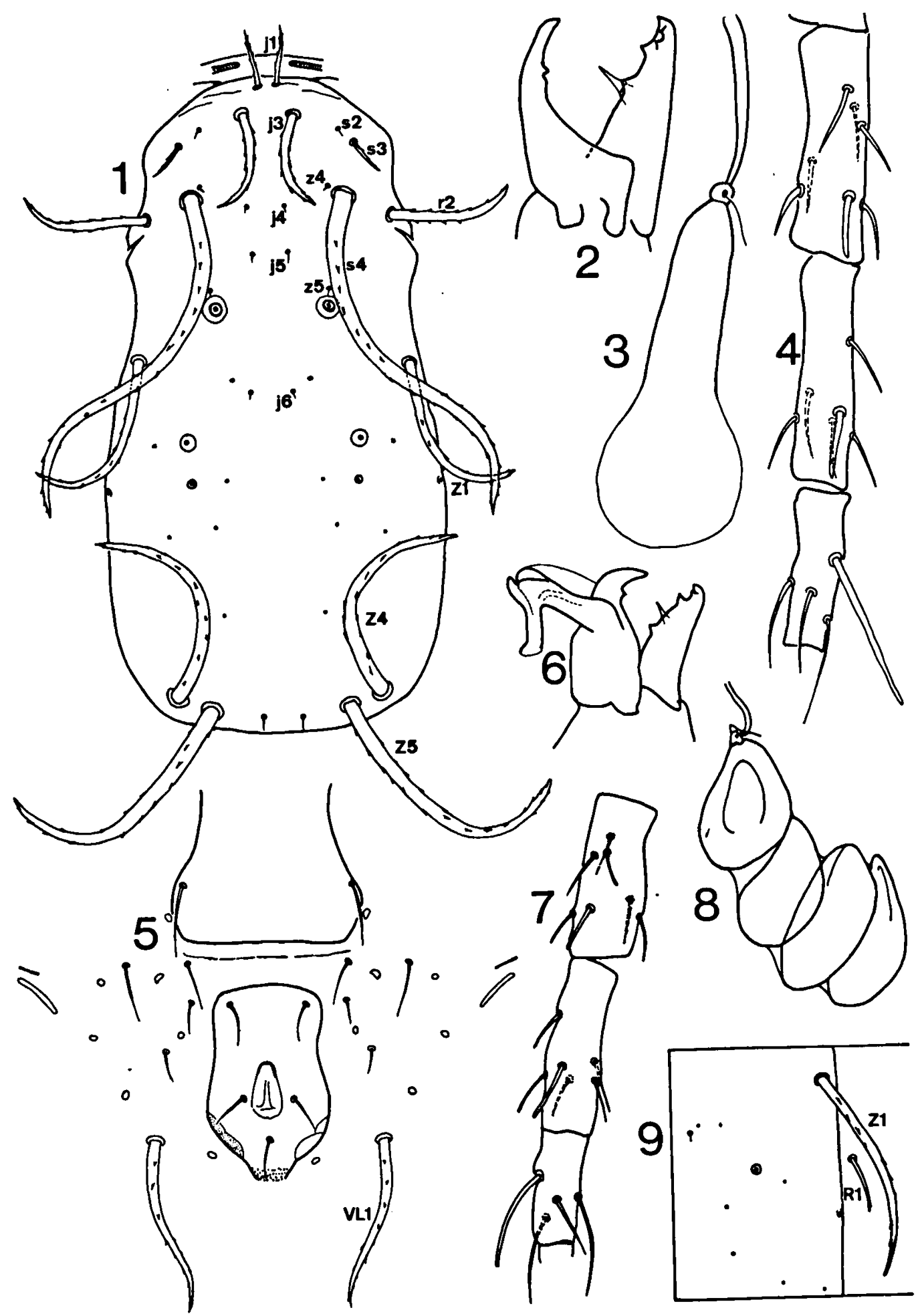

Figs. 1-6. Phytoseius betsiboka sp. n.: I, dorsum $\% ; 2$, chelicera $\% ; 3$, spermatheca $\% ; 4$, leg IV $\$ ; 5$, genital and ventri-anal shield $\% ; 6$, chelicera $\delta$.

Figs. 7-9. Phytoseius onilahy sp. n.: 7, leg IV $\$ ; 8$, spermatheca $\$$ with four spermatophores; 9 , mediolateral part of dorsal shield $\$$. 
Ventri-anal shield as usual, 100 long, probably separate from the peritremal shields, with three pairs of pre-anals and no pores.

Four blunt macrosetae on leg IV; on basitarsus 34 long. Length of tarsus IV 152.

Chelicera as figured; both digits about 16 long. Fixed digit with three teeth. Movable digit with one; spermatophoral process gibbet-shaped, major portion 11 long, branch 5 .

Field note. -

Eotetranychus paracybelus Gutierrez, 1967, was found once together with this species (M 30).

Etymology. -

This species is named after the largest river of Madagascar which joins the sea near Majunga.

Phytoseius (Pennaseius) onilahy sp. n. (figs. 7-9)

Material. - Holotype $\%$ (serial no. 47.4) and 12 paratypes (series 47 and $B$ 13; $10 \% q$ and $5 \delta^{\circ} \delta^{\circ}$ were collected from Sida sp. (Malvaceae) in the garden of the Agricultural Station in Tuléar, 9 and 24.1II.1971.

Differential diagnosis. - The possession of setae R1 places $P$. onilahy into the subgenus Pennaseius, in which the presence of only a single pair of preanal setae on the ventri-anal shield of the female, as well as the extreme length of setae $s 4$, as shown by this species, are unique up till now. However, $P$. onilahy is also very similar to $P$. betsiboka, from which it differs, apart from the presence of setae $R 1$, in the absence of the second largest pore of the postscutum and in the size of the spermatheca.

\section{Description. -}

Female: Dorsal shield smooth, 277 long and 160 wide; incised near seta $\mathbf{r}$; arrangement of pores similar to $P$. betsiboka, except for absence of second largest postscutal pore (fig. 9); fifteen pairs of setae on shield, the longer setae thickened, with rows of spines along their length; length: j1 30, j3 61, Z1 102, Z4 116, Z5 134, s3 28, s4 173, r2 54. Remaining dorsal setae $(\mathrm{j} 4, \mathrm{j} 5, \mathrm{j} 6, \mathrm{~J} 5, \mathrm{z4}, \mathrm{z5}$, s2) smooth and minute, less than 6 long. R1 on interscutal membrane, 23 long. Peritremes reach nearly in front of setae $j 1$.

Sternal shield not well visible. Genital shield as usual, 75 wide. Ventri-anal shield 87 long and 55 wide, without pores, with one pair of pre-anal setae. Surrounding membrane with setae and pores arranged as in $P$. betsiboka and two pairs of metapodal platelets; VLl 95 long.

Leg IV with four blunt macrosetae; on both genu and tibia 20 , on both basitarsus and distitarsus 36 . Some other setae on leg IV are also blunt. Remaining legs without distinct macrosetae. Length tarsus IV (including basitarsus) 179.

Both digits of chelicera about 24 long. Number and arrangement of teeth as in P. betsiboka.

Spermatheca as in $P$. betsiboka; major duct 27 long, cervix $30 \times 11$.

Male: Dorsal shield 223 long and 134 wide. Arrangement of pores as in the female. Length of setae: j1 25, j3 55, Z1 59, Z4 68, Z5 66, s3 23, s4 116, r2 45, R1 10. Remaining dorsal setae minute. Ventri-anal shield as in $\boldsymbol{P}$. betsiboka, 96 long.

Four blunt macrosetae on leg IV; on basitarsus 34 , on distitarsus 30. Length of tarsus IV 143.

Chelicera not easily discernable, but probably similar to $P$. betsiboka.

Remark. - A single dorsal seta $\mathrm{J} 2$ is present in two specimens: $47.3 \%$ and $47.7 \delta$.

Discussion. -

Phytoseius betsiboka and $P$. onilahy were placed according to the generally accepted division of the genus Phytoseius in different subgenera on the basis of the absence and presence, respectively, of the sublateral setae R1. A natural relationship is not obvious as the two species do not fit the existing subgeneric division.

Phytoseius betsiboka is placed in the nominate subgenus, but shows notocephalic pores on the dorsum which is typical for a majority of species of the subgenus Pennaseius.

Phytoseius onilahy is correctly classified with the latter subgenus, although species with a single pair of pre-anal setae on the ventri-anal shield are known only from the nominate subgenus.

In addition to this intermingling of "subgeneric" characters, both species resemble each other so closely so as to form a natural species group, distinctly separate from all other known species of Phytoseius. In accordance with the still very imperfect knowledge on phytoseiid taxonomy, I have refrained from creating another subgenus, and have classified $P$. betsiboka and $P$. onilahy conservatively, without regard of relationships. 
Etymology. -

$P$. onilahy derives its name from the river flowing South of Tuléar.

\section{Phytoseius (Pennaseius) hongkongensis Swirski \& Shechter, 1961}

Phytoseius (Phytoseius) hongkongensis Swirski \& Shechter, 1961: 99, figs. 1-5; Denmark, 1966: 44, fig. 17.

Phytoseius (Pennaseius) hongkongensis; Ehara \& Lee, 1971: 70, figs. 32-37; Ehara, 1972: 169, fig. 81.

Material. - One $\$$ (A 9.25) collected on Pueraria javanica (Papilionaceae), Ivoloina, Tamatave, 7.VII.1972. One \& (A 16.2) from the same plant in the same locality, 16.VII.1972. One (A 22.5) from Stylosanthes gracilis (Papilionaceae), 25.VII.1972 and seven $\$$ \& (A 27 series) from Solanum auriculatum (Solanaceae), 28.VII.1972, also near Ivoloina.

Diagnosis. - Denmark (1966) combined $P$. hongkongensis, $P$. amba Pritchard \& Baker, 1962 and $P$. minutus Narayanan, Kaur \& Ghai, 1960, in the hongkongensis group of species. To this group, $P$. kapuri Gupta, 1969, should be added. In fact, these four forms are so similar, as to make their specific rank rather doubtful in my opinion. The lengths of some setae are the only distinguishing characters, and in this respect the specimens from the East Coast agree well with $P$. hongkongensis.

Female: Setal dimensions: j1 23-27, j3 62-68, z1 77-82, Z4 71-80, Z5 70-73, s3 42-45, s4 87-96, r2 37-43, VL1 48-54; macrosetae genu IV $22-27$, tibia IV $28-30$, basitarsus IV $22-25$, distitarsus IV 23-25.

Remark. - In Blommers \& Gutierrez (1975) this species was listed erroneously as $\boldsymbol{P}$. amba.

\section{Phytoseius (Pennaseius) amba Pritchard \& Baker, 1962}

Phytoseius (Pennaseius) amba Pritchard \& Baker, 1962: 224, figs. 11-12.

Phytoseius (Phytoseius) amba; Denmark, 1966: 46, fig. 18. Typhlodromus (Phytoseius) amba; Van der Merwe, 1968: 101, figs. $233-240$.

Material. - Five $\% \propto$ and one $\delta$ (17 series) from a not identified ornamental species of Malvaceae at TananariveTsimbazaza, altitude $1250 \mathrm{~m}, 8.11 .1971$. One \& (T 2.2) on Euphorbia pulcherrima (Euphorbiaceae), in the same locality, 18.VII.1971.

Diagnosis. - As mentioned above, $P$. amba is very closely related to $P$. hongkongensis, $P$. minu- tus and $P$. kapuri. The setal dimensions of the Malagasy specimens are in almost complete agreement with those given by Van der Merwe (1968) for South African P. amba.

Female: Setal dimensions: j1 19-25, j3 50-56, Z1 71-78, Z4 59-65, Z5 64-77, s3 19-31, s4 78-82, r2 37-44, VL1 54; macrosetae genu IV $23-27$, tibia IV 30-36, basitarsus IV 30-34, distitarsus IV 28-32.

Iphiseius (Iphiseius) degenerans (Berlese, 1889)

Seius degenerans Berlese, 1889.

Iphiseius degenerans; Evans, 1954: 517, figs. 1-10; AthiasHenriot, 1957: 335, fig. 3B.

Iphiseius (Iphiseius) degenerans; Pritchard \& Baker, 1962: 299, figs. 65-66; Van der Merwe, 1968: 105, figs. 241-249.

Material. - One $\&$ (71.1), 27.I.1971, one $\&$ (T 7.1), 16.IX.1971, and two $\%$ (21.1 and 21.2), 9.XI.1971 from Fraxinus berlandieriana (Oleaceae) in Tananarive-Tsimbazaza. In the same locality, one $\delta$ (T 3.3) from Hibiscus rosa-sinensis (Malvaceae). 29.VII.1971, one $\circ$ (T 8.5) from an unidentified plant, 16.IX.1971, and one $\$$ (T 21.1) from lemon (Citrus limon; Rutaceae), 26.IX.1972. One $\delta$ (T 11.1) from papaya (Carica papaya; Caricaceae) in Tananarive-Nanisana, 21.IX.1971, and one $\&$ (T 17.1) from coffee (Coffea arabica; Rubiaceae) at Ambatomena, $30 \mathrm{~km} \mathrm{N.E.} \mathrm{of} \mathrm{Tananarive,}$ 2.XII.1972.

Diagnosis. - The specimens are in perfect agreement with the available descriptions.

Iphiseius (Trochoseius) gongylus Pritchard \& Baker, 1962 (figs. 10-13)

Iphiseius (Trochoseius) gongylus Pritchard \& Baker, 1962: 304, figs. $69-70$.

Material. - Six $q q$ and four $\delta \delta$ (series A 10) were collected from lemon leaves (Citrus limon; Rutaceae) at Ivoloina, Tamatave, 8.VII.1972; one $\&$ (A 28.1) in the same locality, 29.VII.1972; three $\& \&$ and three $\delta \delta$ (A 29 series) from combava (Citrus histrix) in the same plantation as the other specimens, 29.VII.1972.

Diagnosis. - There can be little doubt about the identification of this peculiar phytoseiid mite.

Female: Large, bright red in life, in preparation brownish. Dorsal shield 380 long and 335 wide. Length of dorsal setae: j1 29, j3 54, Z1 18, Z4 (?) 225 , s4 196, S2 214; remaining setae minute, less than 10 long. Sublaterals $\mathrm{r} 2$ and R1 also small, about 8 . 


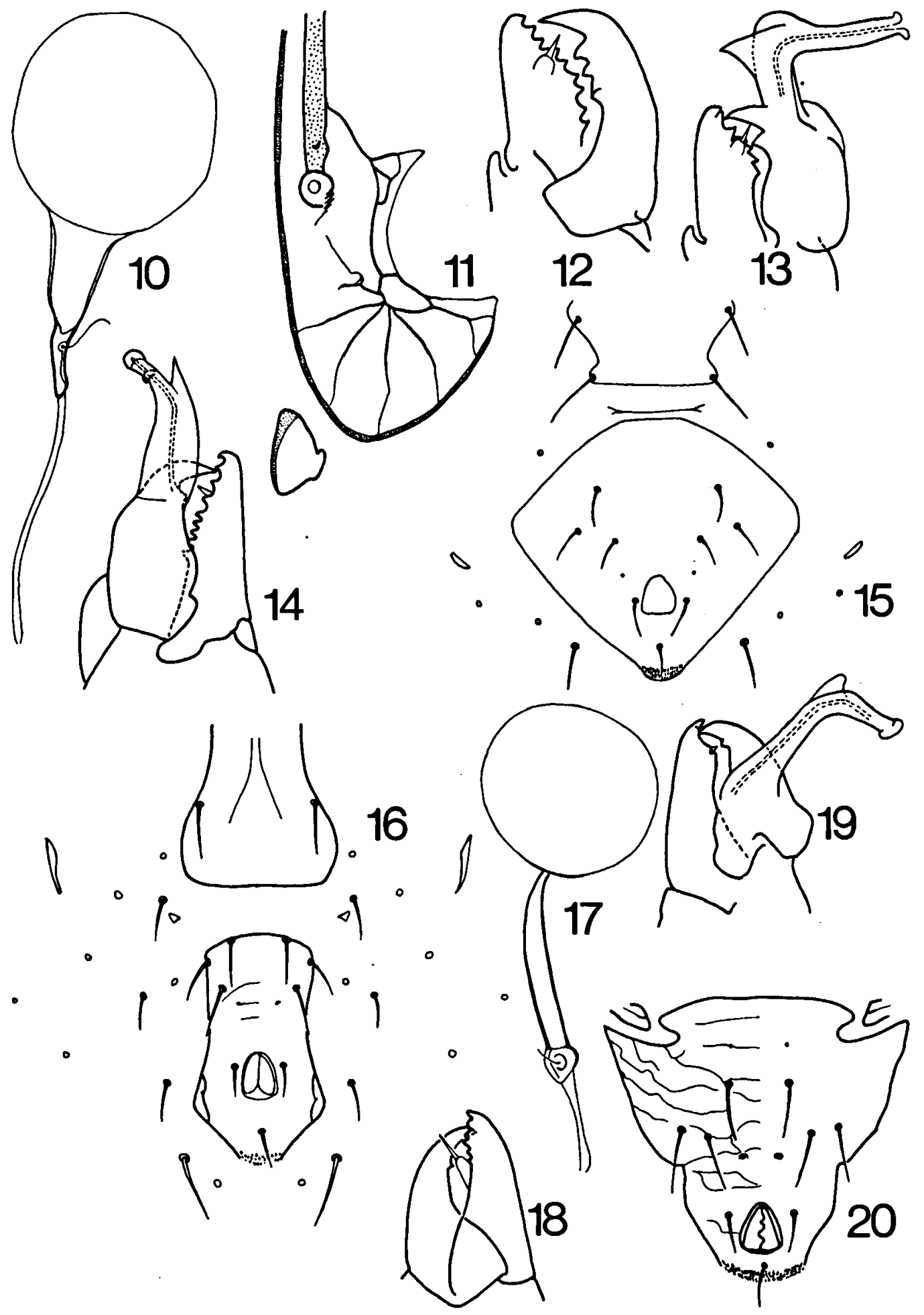

Figs. 10-13. Iphiseius gongylus Pritchard \& Baker, 1962: 10, spermatheca \%: 11, peritremal plate $q ; 12$, chelicera $q ; 13$, chelicera $\delta$.

Figs. 14-15. Paraphytoseius multidentatus Swirski \& Shechter, 1961: 14, chelicera of : 15, genital and ventri-anal shield $\delta$.

Figs. 16-20. Amblyseius hima Pritchard \& Baker, 1962: 16, genital and ventri-anal shield $\$ ; 17$, spermatheca $\% ; 18$, chelicera $\$ ; 19$, chelicera $\delta ; 20$, ventri-anal shield $\delta$. 
Venter as figured with original description. Ventri-anal shield 170 long and 230 wide.

Length tarsus IV 170. Length of macrosetae: on genu IV 43 and 102, tibia IV 70, basitarsus IV 62, genu III 60, tibia III 48, genu I 54.

Chelicera as in fig. 12; fixed digit 20 , movable digit 25 long.

Spermatheca as in fig. 10; major duct 18, atrium 7, cervix 13 long.

Male: Dorsal shield 315 long and 260 wide. Length of long setae: j1 and j3 25, Z4 205, s4 and S2 180.

Genitosternal and ventri-anal shield reticulate as in female. Ventri-anal shield 170 long and 205 wide, not fused with peritremal shields, with three pairs of pre-anal setae, and one pair of pronounced pores at the same level as the posterior pair of pre-anal setae.

Length tarsus IV 140. Length macrosetae on legs: genu IV 107, tibia IV 80 , basitarsus IV 58, genu III 50, tibia III 45, genu I 50.

Fixed digit of chelicera 16 long, movable digit 20. Major portion of spermatophoral process 12 , branch 23 .

\section{Paraphytoseius multidentatus}

Swirski \& Shechter, 1961 (figs. 14-15)

Paraphytoseius multidentatus Swirski \& Shechter, 1961: 114, figs. 7, 26-28.

Amblyseius (Paraphytoseius) multidentatus; Ehara \& Lee, 1971 69 , figs. 26-31.

Material. - East coast: $3 \% \%$ (T 14 series) were collected from Phaseolus lunatus (Papilionaceae) and 19 (T 15.1) from Sechium edule (Cucurbitaceae) at Bains des Dames, Tamatave City, 18.X.1971. In the same locality, 1 \& (A 11.1) from $P$. lunatus, 12.VII.1972. At Ivoloina, Tamatave, $3 \% q$ and $1 \delta$ (A 6 series) were found on $P$. lunatus, 11.11.1972. In the same locality on Pueraria javanica (Papilionaceae), $3 \propto q$ and $3 \delta$ (A 9 series), 7.VII.1972, $2 \%$ and $1 \delta$ (A 16 series), 16.VII.1972, and $3 \% q$ and $2 \delta \delta^{\circ}$ (A 30 series), I.VIII.1972.

West coast: 11 \& $\circ$ (M 10 series) were collected from Urena lobata (Malvaceae), I \& (M 18.4) from Alchornea sp. (Euphorbiaceae) and $1 \delta$ (M 20.3) from Phaseolus sp., all at Ambato Boeni, 24.VI.1972. On the same day, 6 \% \% (M 15 series) were found on Leonotis nepetaefolia (Labiatae) at Ampijoroa, Tsaramandroso. On 9 and 24.111.1971, $6 \%$ and $4 \delta$ $\delta$ (47 series) were collected from Sida sp. (Malvaceae) in the botanical garden of the Agricultural Station at Tuléar. On 25.IV.1971, 13 \% $\%$ and $2 \delta \delta$ (B 13 series) were found on the same plants in the same place.

Diagnosis. - Only six species of the genus Paraphytoseius Swirski \& Shechter, 1961, have been described: $P$. multidentatus (Hong Kong), $P$. hor- rifer (Pritchard \& Baker, 1962) (Zaire), P. santurcensis De Leon, 1965 (Puerto Rico), P. crascentis (Corpuz \& Rimando, 1966) (Philippines), $P$. narayanani (Ehara, 1967) (India) and $P$. urumanus (Ehara, 1967) (Okinawa). The differences between the above are often slight, being mainly based on setal dimensions, and the number of specimens studied is low so that the specific status of several is questionable.

As far as pertinent descriptions exist, my specimens agree best with $P$. multidentatus; the dimensions of the larger dorsal setae and the macrosetae of leg IV fall within the same range, except for dorsal seta Z5. Compared with $P$. urumanus, six setae are different, with $P$. santurcensis nine, and with $P$. horrifer eleven out of twelve.

There exist some small differences between the specimens from the East coast and those from the West coast of Madagascar. The latter agree with the original description of $P$. multidentatus in having some small rod-like setae on leg IV and the macroseta on basitarsus IV considerably longer than on distitarsus IV. The specimens from Tamatave, however, have all setae, except the macrosetae and one small seta on the femur, acuminate and both macrosetae on tarsus IV of nearly the same length, as in the topotype series described by Ehara \& Lee (1971).

Female: Dorsal shield 280-295 long and 155160 wide; with at least twenty pairs of pores, those near setae $\mathrm{z} 5$ very pronounced. Dimensions of the larger, serrate setae: $\mathrm{j} 130-36, \mathrm{j} 3 \mathrm{79}-89$, Z4 68-80, Z5 96-116, s4 118-130, r2 36-48, R1 23-35. Remaining setae smooth and less than 10 long. Peritremes reach in front of setae jl.

Venter as described by Ehara \& Lee (1971). Ventri-anal shield 102-108 long and 59-63 wide, with a pair of minute pores. VL1 $63-82$ long.

Leg IV with four distinct macrosetae: on genu $22-27$, tibia $28-38$, basitarsus $38-45$ and distitarsus $34-42$. In the specimens from the East coast, all remaining setae on the legs acuminate, except the most proximal seta on femur IV, and one seta on genu II, which are both rod-shaped. The specimens of the West coast with a rodshaped seta on femur IV, genu IV (often two), tibia IV, basitarsus IV and genu II.

Spermatheca as usual in Paraphytoseius; long 
and slender major duct $(20 \times 2)$, knob-like atrium, platter-shaped cervix, about 7 in diameter; vesicle filled with spermatophore, globular, about 30 in diameter. Spermatophore itself pearshaped.

Fixed digit of chelicera with about eight teeth, movable digit with three.

Male: Peritremes shorter than in the female, not reaching as far as base of setae $j 3$. Dorsal shield 220 long and 140 wide, incised near setae $s 4$ as in the female. Large pores near setae $\mathrm{z5}$. Length of the larger serrate setae: $\mathrm{j} 127, \mathrm{j} 355, \mathrm{Z} 4 \mathrm{48}, \mathrm{Z} 560$, r2 30, R1 13. The latter two located on the shield. Remaining dorsal setae smooth and minute.

Three pairs of pre-anal setae and one pair of pores on ventri-anal shield. VL1 22 long.

Macrosetae and rod-like setae on legs as in female. Length of macrosetae: genu IV 20, tibia IV 30, basitarsus IV 33, distitarsus IV 30-35.

Chelicera as figured (after A 9.24). The pointed structure halfway the spermatophoral process seems less pronounced in the West coast specimens. Length of both digits about 20 , spermatophoral process 17. Fixed digit with about eight teeth, movable digit with one.

Field notes. -

This species was observed frequently on plants which harboured also the tetranychid mite species Tetranychus macfarlanei Baker \& Pritchard, 1960 (T 14, T 15, A 6, A 11, A 30) and Eotetranychus limoni Blommers \& Gutierrez, 1975 (A 9) in the region of Tamatave, and $T$. neocaledonicus André, 1933 (B 13) in Tuléar. Unsuccess-

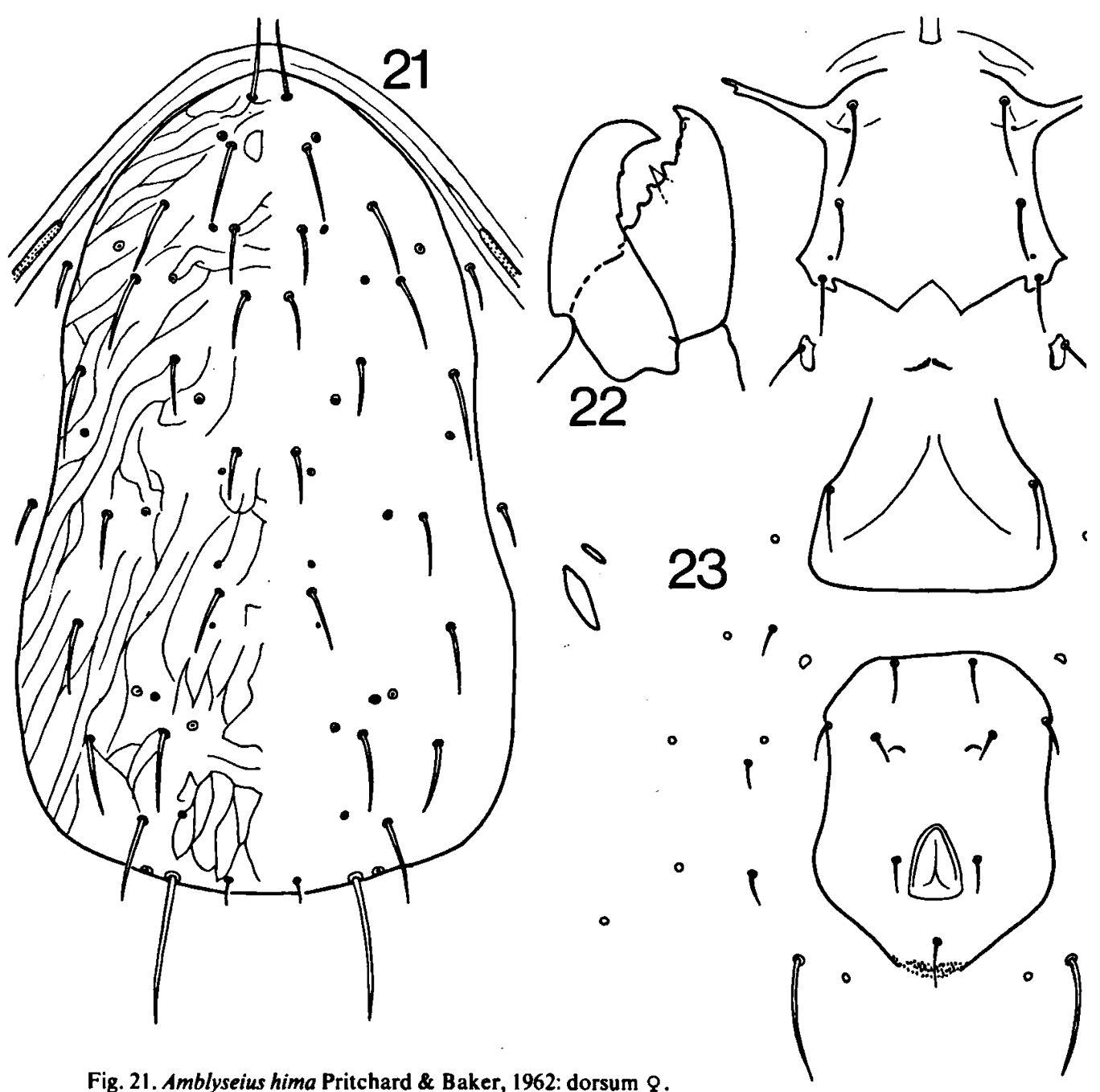

Figs. 22-23. Amblyseius hova sp. n.: 22, chelicera $\$ ; 23$, venter $\%$. 
ful attempts to rear $P$. multidentatus using the latter spider mites as prey, suggest that this phytoseiid mite is not a predator of Tetranychus mites.

\section{Amblyseius (Amblyseius) hima \\ Pritchard \& Baker, 1962 (figs. 16-21)}

Amblyseius (Amblyseius) hima Pritchard \& Baker, 1962: 257, figs. $36-37$.

Material. - At Tsimbazaza, Tananarive (alt. $1300 \mathrm{~m}$ ), $13 \%$ \% and $1 \delta$ (series T 1) were collected on leaves of Euphorbia pulcherrima (Euphorbiaceae), 18.VII.1971; $15 \% q$ and $3 \delta \delta$ (series $T$ ) on Thunbergia grandiflora (Acanthaceae), 7.IX.1971; 1 \& (T 6.3) on Barleria sp. (Acanthaceae), 16.IX.1971; 3 \% $\%$ and $1 \%$ (series 20) on Dombeya sp. (Sterculiaceae) in January 1971.

Diagnosis. - The original description is based on specimens from Ruanda Urundi, and the Malagasy specimens, though of smaller size, agree well with the originals.

Female: Dorsal shield imbricated, 280-300 long, 168-175 wide; with at least fifteen pairs of pores. Length dorsal setae: j1 20-21, j3 27, j4 20, j5 18-20, j6 18-20, J2 20-21, J5 5-6, z4 $30-32$, z5 18-20, Z1 20-21, Z4 23-25, Z5 $45-50$, s2 27-29, s4 34-36, S2 25-27, S4 23-25, S5 25-27, r2 21, R1 18. Peritremes do not reach much further than sublaterals $r 2$.

Sternal shield posteriorly with median lobe. Ventri-anal shield agrees with original description; 82-86 long and 46-54 wide. Surrounding membrane with six pairs of pores and four pairs of setae; VL1 29-30 long. One pair of metapodal platelets.

Tarsus IV 100 long, macrosetae on it 38-43.

Spermatheca as figured, major duct 11, cervix 20 long; atrium 3, vesicle 19 in diameter. Digits of chelicera 22 long.

Male: Dorsal shield anteriorly imbricated, 230 long and 135 wide. Length of setae: j1 21, j3 25, j4 18 , j5 16, j6 18, J2 16, J5 5, z4 26, z5 18, Z1 18, Z4 20, Z5 40, s2 24, s4 29, S2 20, S4 20, S5 22, r2 22, R1 16. Sublaterals $r 2$ and $R 1$ on dorsal shield. Peritremes as in female.

Ventri-anal shield 86 long, not fused with peritremal shield; only two pairs of pores visible; three pairs of pre-anals. VL1 23.

Macroseta on basitarsus IV 32 long.

Chelicera as figured, digits 18 long, spermatophoral process gibbet-shaped. Major portion 18 long, branch 9.
Field notes. -

The plants on which this phytoseiid was found often harboured considerable numbers of the tenuipalpid Brevipalpus sp. (T 1, T 5, T 6) as well as tydeid mites and scale insects (T $1, T$ ).

\section{Amblyseius (Amblyseius) hova sp. n. (figs. 22-26)}

Material. - Holotype $\odot$ (T 3.5) and 1 paratype $\%$ (T 3.4) from Hibiscus rosa-sinensis (Malvaceae), TananariveTsimbazaza, alt. $1250 \mathrm{~m}, 29$. VII.1971; 3 paratypes ( $q$ ) (T 6 series) from Barleria sp. (Acanthaceae) and 1 paratype ( $Q$ ) (T 8.10) from an unidentified plant, both in the same locality as the holotype, 16.IX.1971. Two young, not yet fully sclerotized ㅇ ( $\mathrm{T}$ 10A series) collected on lemon (Citrus limon; Rutaceae), 1 \& (T 11.2) on papaya (Carica papaya; Caricaceae), both in Tananarive-Nanisana, 21.IX.1971, and 1 \% (T 5.13) on Thunbergia grandiflora (Acanthaceae), Tsimbazaza, 7.IX.1971 belong to the same species.

Differential diagnosis. $-A$. hova bears a close resemblance to South African $A$. munsteriensis Van der Merwe, 1965. It differs markedly from this species in the shape of the spermatheca.

\section{Description. -}

Female: Dorsal shield rather strongly imbricated; 340 long and 215 wide, with at least thirteen pairs of pores. Seventeen pairs of setae; length: j1 23, j3 25, j4 12, j5 11, j6 13, J2 14, J5 9, z4 20, z5 13, Z1 14, Z4 20, Z5 72, s2 20, s4 23, S2 20, S4 22, S5 22. Z5 smooth. Sublaterals $\mathrm{r} 2$ and R1.on interscutal membrane, 16 and 12 long, respectively. Peritremes reach in front of setae $\mathrm{jl}$.

Posterior margin of sternal shield W-shaped. Genital shield as usual. Ventri-anal shield 104 long and 77 wide, with three pairs of pre-anals. Surrounding membrane with six pairs of pores, and four pairs of setae; VL1 42 long.

Length tarsus IV 116. Macrosetae on genu IV 36, tibia IV 30, basitarsus IV 86, genu III 25 long. No other macrosetae present. Chaetotaxy of legs normal.

Chelicera not easily discernable in type series, about 25 long. Fig. 22 is drawn after specimen $\mathrm{T}$ $10 \mathrm{~A} 5$.

Spermatheca small, cervix funnel-shaped, 12 long.

\section{Male: Unknown.}

Field notes. -

Various species of small arthropods were observed in the direct vicinity of $A$. hova, such as Brevipalpus sp. (T 5, T 6, T 10) and Tetranychus 
neocaledonicus ( $\mathrm{T}$ 3, $\mathrm{T}$ 10), unidentified Tydeidae and white flies (Aleurodidae) (both T 3), but there was no indication that the phytoseiid uses any of them for food.

Etymology. -

The Hova were of old the free men of the Merina, inhabitants of the highlands around Tananarive.

\section{Amblyseius (Amblyseius) masiaka}

Blommers \& Chazeau, 1974

Amblyseius (Amblyseius) masiaka Blommers \& Chazeau, 1974: 308, figs. 1-7.
Material, - One $\%$ (M 32.1) collected on Hibiscus sp. (Malvaceae) at Ampijoroa (Majunga province), 30.XI.1972. Four $\$ \%$ and four $\delta \delta$ (M 22-2k series) from a mass rearing started with specimens found on several herbs near Katsepy (Bombetoka Bay, opposite Majunga), 27.IV.1972.

Diagnosis. - These specimens are identical to the type series from Tuléar.

Amblyseius (Amblyseius) bibens Blommers, 1973

Amblyseius (Amblyseius) bibens Blommers, 1973: 111 figs. 1218.

Material. - Tuléar: $4 \%$ (B 3 series) from Carica papaya (Caricaceae), 3.III.1971; $8 \% \varnothing$ and $2 \delta^{\circ}$ (B 4 and 40 series)

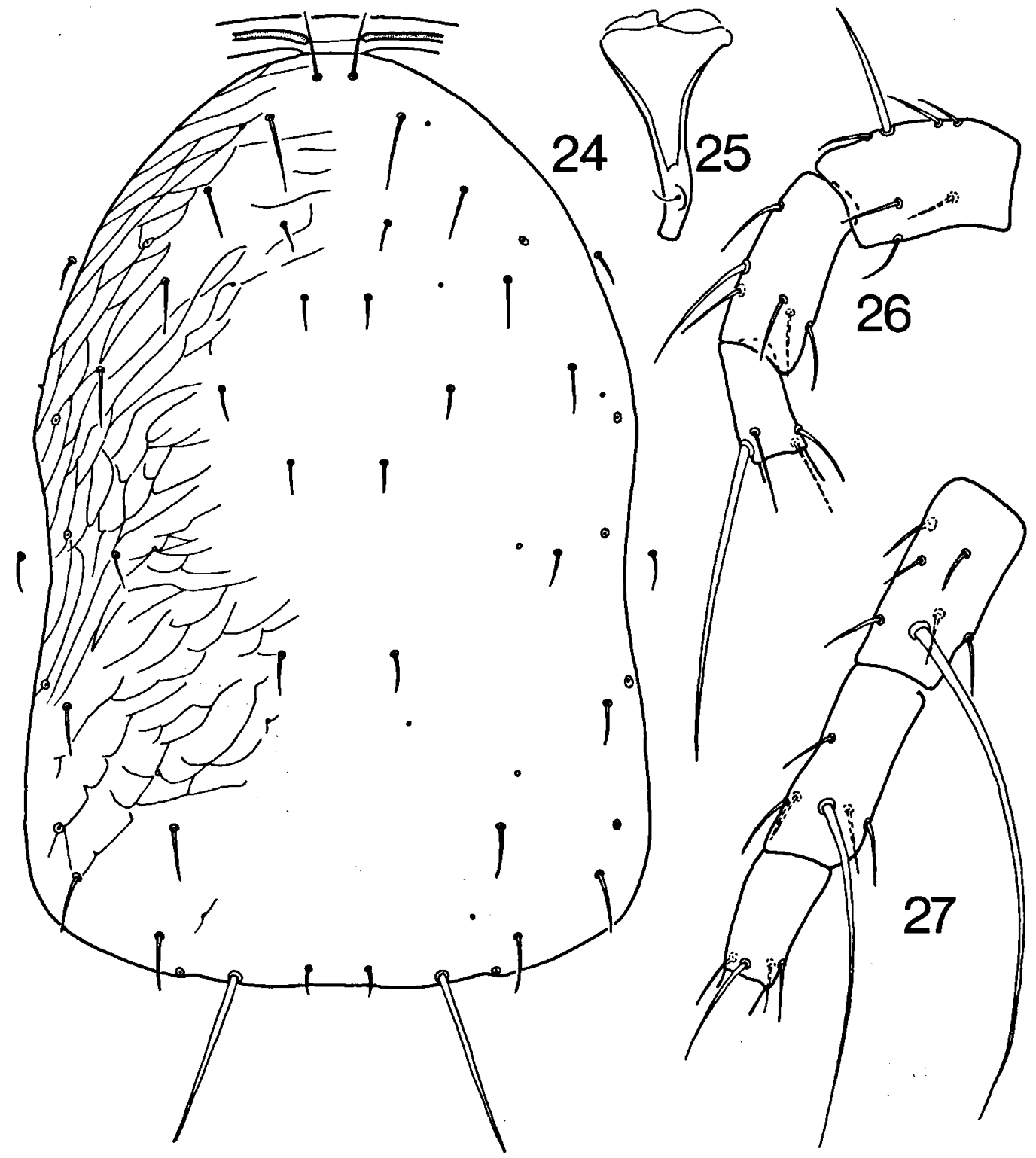

Figs. 24-26. Amblyseius hova sp. n.: 24, dorsum $\% ; 25$, spermatheca $\% ; 26$, leg IV $\%$

Fig. 27. Amblyseius ankaratrae sp. n.: leg IV $\%$. 
from Sida spinosa (Malvaceae), 5.111.1971; 2 \% (B 6 series) from Sida sp., 6.III.1971; 2 \% 9 (B 7 series) from Leonotis nepetaefolia (Labiatae), 4.III.1971; 3 우 (B 15 series) from Corchorus trilocularis (Tiliaceae), 9.1II.1971; 6 \% (B 23 and 57 series), $6 \% \%$ (62 series) and $2 \% \%$ and $1 \%$ (65 series) from the same plant species on 24.III, 26.III and 2.IV.1971, respectively; $6 \%$ (B 22 and 61 series) from Corchorus olitorius, 24.III.1971; 6 \% $ᄋ$ (B 24 series) from Abelmoschus esculentus (Malvaceae), 25.III.1971; 2 ㅇ (B 34 series) from cotton (Gossypium hirsutum; Malvaceae), 20.III.1971; 2 \& from Manihot utilissima (Euphorbiaceae), 15.V.1971.

Tananarive: $12 \% \%$ and $1 \delta$ (T 25 series) from Phaseolus vulgaris (Papilionaceae) at Tananarive-Soanierana (alt. 1300 m), 14.III.1973.

Tamatave: Apart from the specimens recorded previously from this region (Blommers, 1974a), this species was also encountered at Bains des Dames, Tamatave City, on Phaseolus lunatus (Papilionaceae) ( $3 \% \&$ and $1 \delta ; T 14$ series), Sechium edule (Cucurbitaceae) ( $3 \% \%$ T 15 series) and

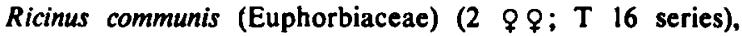
18.X.1971.

Field notes. -

This predacious mite was encountered always in or near populations of spider mites of the genus Tetranychus: $T$. neocaledonicus in the region of Tuléar, $T$. macfarlanei near Tamatave and $T$. urticae Koch, 1836, and T. ludeni Zacher, 1913, in the central highlands.

\section{Amblyseius (Amblyseius) rotundus}

Blommers, 1973

Amblyseius (Amblyseius) rotundus Blommers, 1973: 111, figs. 19-25.

Material. - Tulćar: $7 q q$ and $1 \delta$ (B 9 and 66 series) from Mangifera indica (Anacardiaceae), 5.III.1971; 5 ९ (B 10 and 52 series) from Acalypha sp. (Euphorbiaceae), 8.III.1971; 11 $\uparrow ᄋ$ (B 20 and 55 series) from Croton sp. (Euphorbiaceae), 11.III.1971; 4 우 (56 series) from Echinochloa colonna (Gramineae), 22.III.1971; $6 \%$ and $3 \delta \delta$ (57 series) from Corchorus trilocularis (Tiliaceae), 24.III.1971; 2 우 (B 24 series) from Abelmoschus esculentus (Malvaceae), 25.III.1971; from the same plant $3 q \%$ and $I \delta$ (60 series), 6.IV.1971; $1 \delta$ (B 29.1) from Sida sp. (Malvaceae), 6.IV.1971; 1 \& (B 33.4) from Acalypha sp. (Euphorbiaceac), 13.IV.1971; 3 우 (B 34 series) from cotton (Gossypium hirsutum; Malvaceae), 20.IV. 1971; 2 \% $\%$ and 1 (B 35 series) from Bauhinia sp. (Caesalpinaceae), 11.IV.1971; and $6 \% \%$ from manioc (Manihot utilissima; Euphorbiaceae), 15.V.1971.

Majunga-Katsepy: 1 \& (M 1.3) from unidentified Asclepiadaceae, 26.IV.1971; 1 o and $1 \delta$ (M 3 series) from an unknown plant; 1 \& (M 7.1) from Rhopalocarpus lucidus (Rhopalocarpaceae); $4 \% q$ and 1 ( 99 series) from Bauduinia sp. (Caesalpinaceae) and $7 \% q$ and $2 \delta$ (M 16 series) from Diospyros sp. (Ebenaceae). All collected on the same date as the first.

Ambato Boeni/Ampijoroa: $3 \% q$ (M 6 series) from Ricinus communis (Euphorbiaceae) at Ampijoroa, 24.IV.1975; 25 \& and 1 (M 11 series) from Plumeria alba (Apocynaceae) at Ambato Boeni on the same day.

Amblyseius (Amblyseius) brevipes Blommers, 1973

Amblyseius (Amblyseius) brevipes Blommers, 1973: 112, figs. 26-28.

Material. - Tuléar: except for in the type locality, this species (1 \&; 52.8) was also collected on Acalypha sp. (Euphorbiaceae), 8.1II.1971.

Ambato Boeni/Ampijoroa: 4 \& (M 17 series) from Carica papaya (Caricaceae) in Ampijoroa, 24.IV.1972; 3 \% $q$ (M 20 series) from Phaseolus (?) sp. near Ambato Boeni on the same date as the first; 1 \% (M 26.21) from Alchornea sp. (Euphorbiaceae) in Ambato Boeni, 12.IX.1972.

Tamatave: $13 \% q$ and $1 \delta$ (A 4 series) from $C$. papaya at the I.F.A.C.-station in Ivoloina, 8.II.1972.

Tananarive: 6 \% $\%$ (T 6 series) from Barleria sp. (Acanthaceae) at Tsimbazaza (1250 m), 16.IX.1971; on the same place at the same date $7 \% q$ (T 7 series) from Fraxinus berlandieriana (Oleaceae) and $12 \% \%$ and $1 \%$ (T 8 series) from the undergrowth under these trees. At Tananarive-Nanisana, 1 \% (T 11.4) was collected on C. papaya, 21.IX.1971.

Discussion. -

Amblyseius rotundus and $A$. brevipes have been found to be more intimately related than realized at the time of their original description. The original diagnosis appeared to be insufficient to discriminate between them over their whole area of occurrence. The following biometrical study is meant to provide these means. Other morphological characters such as the shape of the spermatheca and of the chelicera were not taken into consideration as they are difficult to quantify. We have measured the longer setae, notably those on leg IV, and the length of the same leg (genu, tibia, basi- and distitarsus), since these constituted also the major distinguishing marks between the two species according to the original description.

In table I and fig. 65 (p. 102) the measurements are combined in seven groups. The data show a clear difference between $A$. rotundus and $A$. brevipes in the region of Tuléar, their type locality. Evidently, the specimens from Tamatave (all from $C$. papaya) and two samples from Ambato Boeni/Ampijoroa (from C. papaya and Phaseolus sp.) belong also to $A$. brevipes. On the other hand, the animals collected on the dune vegetation in Majunga/Katsepy are certainly $A$. rotundus.

The two remaining groups are more difficult to assign. The other two samples (from Plumeria and from Ricinus) from the region of Ambato Boeni/ 
Table I. Size (mean and standard deviation) of leg IV (femur - distitarsus) and the macrosetae on genu and basitarsus of the same leg in grouped female specimens in the Amblyseius rotundus-brevipes complex.

\begin{tabular}{lcccccccccc}
\hline & \multicolumn{2}{c}{ seta genu IV } & \multicolumn{3}{c}{ seta basitarsus IV } & length leg IV & length leg IV & N & $\begin{array}{c}\text { No. samples } \\
\text { (= plants) }\end{array}$ \\
& $\bar{x}$ & SD & $\bar{x}$ & SD & $\dot{x}$ & SD & & seta genu IV & & \\
\hline A. Tuléar brevipes & 40.0 & 1.9 & 65.0 & 2.5 & 287 & 10.9 & 7.1 & 13 & 4 \\
B. Ambato Boeni/Ampijoroa brevipes & 40.5 & 2.4 & 62.5 & 1.3 & 290 & 16.9 & 7.1 & 7 & 2 \\
C. Tamatave & 44.0 & 2.2 & 64.5 & 2.4 & 292 & 7.2 & 6.7 & 7 & 1 \\
D. Tananarive & 47.5 & 3.0 & 74.0 & 3.7 & 332 & 9.4 & 7.0 & 16 & 4 \\
\hline E. Ambato Boeni/Ampijoroa rotundus 52.5 & 2.7 & 72.0 & 4.2 & 301 & 6.6 & 5.8 & 9 & 2 \\
F. Tuléar rotundus & 58.5 & 3.2 & 79.0 & 2.8 & 319 & 9.8 & 5.4 & 29 & 10 \\
G. Majunga Katsepy & 61.5 & 4.5 & 79.0 & 4.8 & 303 & 13.7 & 4.9 & 12 & 5 \\
\hline
\end{tabular}

Ampijoroa are sufficiently different from those identified as $A$. brevipes from the same region, to be named $A$. rotundus. Certainly so, if one knows that in Ampijoroa Carica papaya (with brevipes) and Ricinus communis (with rotundus) grew side by side.

The specimens from Tananarive, finally, have rather long macrosetae, but also the longest legs of all specimens examined. If this latter dimension is considered as a measure for the body size, which itself is difficult to determine in mounted specimens, the relative lengths of the macrosetae are entirely comparable with those found with the other $A$. brevipes (see table I). Therefore, we are strongly inclined to assign them to this species.

\section{Amblyseius (Amblyseius) ankaratrae sp. $\mathrm{n}$.}

(figs. 27-32)

Material. - Holotype $q$ (T 4.1) and four paratypes (3 $\%$ and $1 \delta$ ) from Dicoryphe sp. (Hamamelidaceae) in mountain rain forest, Manjakatompo Forest Station, Ankaratra Mountains, alt. $1900 \mathrm{~m}, 14$.VIII. 1971 .

Differential diagnosis. - The combination of an elongate, whip-like seta Z5 with a short Z4 is unique among the known species of Amblyseius.

\section{Description. -}

Female: Dorsal shield smooth, with at least twelve pairs of pores; 350 long and 250 wide. Seventeen pairs of setae; length: $\mathrm{j} 120, \mathrm{j} 327, \mathrm{j} 45$, j5 7, j6 9, J2 11, J5 5, z4 11, z5 7, Z1 13, Z4 14, Z5 205, s2 11, s4 13, S2 11, S4 11, S5 11. Sublaterals r2 and $R 1$ on interscutal membrane, 13 and 11 long. Peritremes reaching base of setae jl. A finely striated band bordering the dorsal scutum is clearly visible in mounted specimens.
Sternal and genital shield as usual. Ventri-anal shield 100 long, 75 wide; widest on the level of paranal setae; with three pairs of pre-anal setae. Surrounding membrane with four pairs of pores and four pairs of setae; VL1 18 long.

Length tarsus IV 128. Length of macrosetae: on genu IV 125 , tibia IV 84 , basitarsus IV 32 , genu III 38, tibia III 32, genu II 30, genu I 36.

Fixed digit of chelicera 34 long, with three blunt subapical teeth and eight in row. Movable digit 34 , without teeth.

Spermatheca as in fig. 29. Major duct 16, cervix 7 long.

Male: Dorsal shield 285 long, 180 wide. Length of setae: j1 20, j3 29, j4 5, j5 5, j6 5, J2 9, J5 7, z4 7, z5 5, Z1 11, Z4 9, Z5 170, s2 9, s4 13, S2 9, S4 9, S5 7, R1 9.

Ventri-anal shield imbricated, 115 long; probably fused with peritremal shields; with four preanals and at least four pairs of pores.

Length of macrosetae: on genu IV 70 , on tibia IV 64.

Chelicera in our specimen not entirely visible (fig. 32); length digits 22; fixed digit with one subapical tooth and seven in row. Spermatophoral process gibbet-shaped; major portion 18, branch 7 .

Amblyseius (Amblyseius) boina sp. n. (figs. 33-39)

Material. - Holotype $q$ (M 18.6) and seven paratypes (6 $\%$ \% and $\left(\delta^{\circ}\right)$ were collected on Alchornea sp. (Euphorbiaceae) in degraded savannah brush near Ambato Boeni (Majunga province), 24.IV.1972.

Differential diagnosis. - This species differs from most other Amblyseius species in the combined presence of long whip-like setae $\mathrm{Z4}$ and 


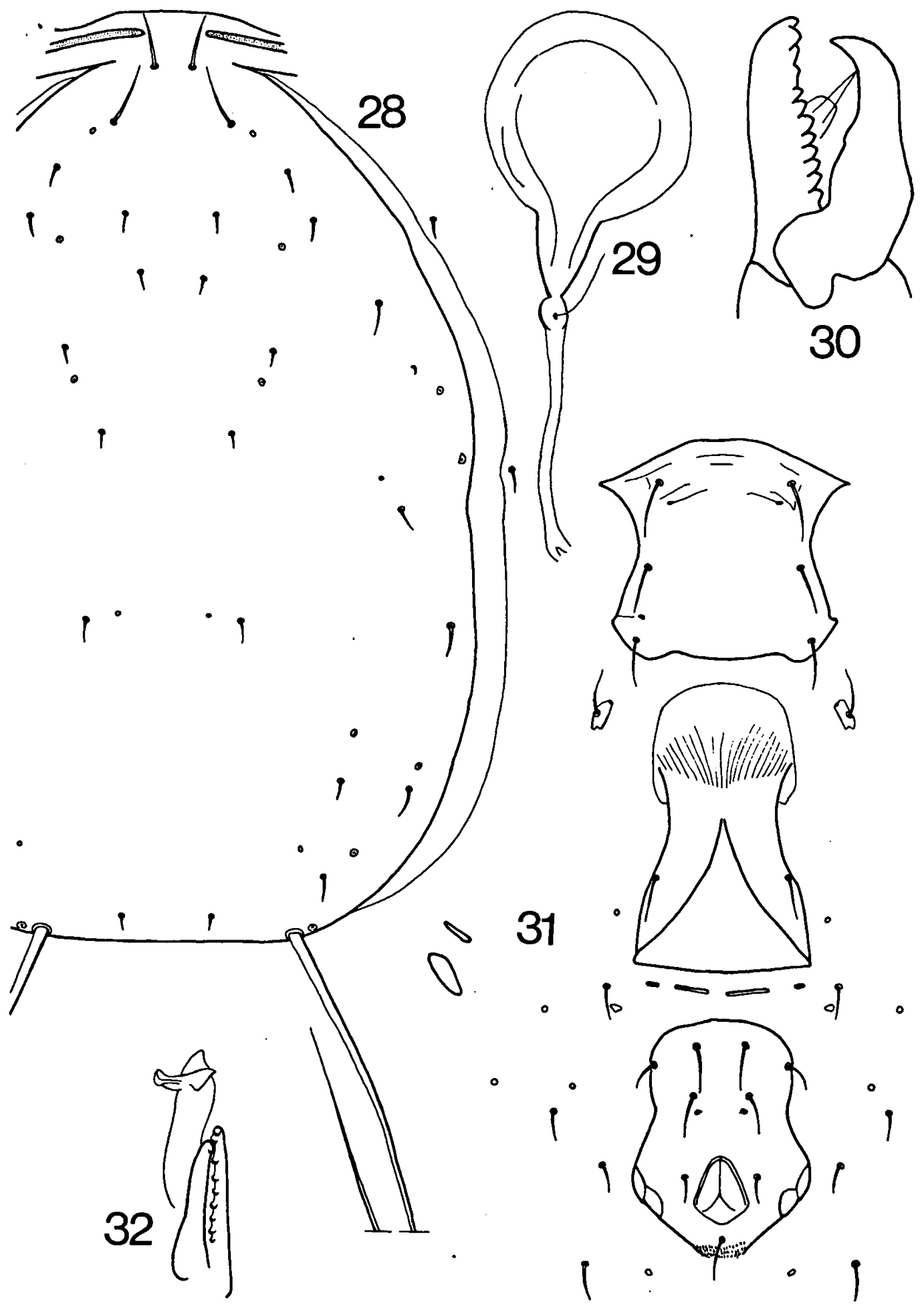

Figs. 28-32. Amblyseius ankaratrae sp. n.: 28, dorsum $\% ; 29$, spermatheca $\% ; 30$, chelicera $\%$; 31 , venter $\$ ; 32$, chelicera 0 . 
$\mathrm{Z5}$, and a feebly pronounced corniform atrium. In this respect, $A$. boina is closely related to $A$. aerialis (Muma, 1955), A. paraaerialis Muma, 1967, A. lassus Schuster, 1966, and A. invictus Schuster, 1966. However, A. aerialis and A. lassus have a more tubular cervix of the spermatheca, $A$. paraaerialis has considerably shorter setae $Z 4$, $\mathrm{Z5}$ and $\mathrm{s} 4$, and $A$. invictus has a knob-like atrium of the spermatheca and a more triangular ventrianal shield.

\section{Description. -}

Female: Dorsal shield smooth, 320 long and 255 wide; with at least fourteen pairs of pores. Seventeen pairs of setae; length: $\mathrm{j} 129, \mathrm{j} 341, \mathrm{j} 45$, j5 4, j6 5, J2 5, J5 7, z4 7, z5 5, Z1 7, Z4 114, Z5 236, s2 7, s4 80, S2 7, S4 8, S5 8. Sublaterals r2 and $R 113$ and 9 long, respectively. Peritremes reach in front of setae $j l$.

Sternal and genital shield as usual. Ventri-anal shield rather narrow, 103 long and 75 wide, with three pairs of pre-anal setae. Surrounding membrane with five pairs of pores and four pairs of setae; VL1 75 long.

Tarsus IV 120 long. Length of macrosetae on legs: genu IV 110, tibia IV 84, basitarsus IV 82, genu III 59, tibia III 42, genu II 40, genu I 45.

Fixed digit of chelicera 25 long, with two subapical teeth, and nine in a row. Movable digit 25 long, with three teeth.

Spermatheca as figured, feebly sclerotized, 45 long. Major duct 22 long and 1 wide, atrium illdefined, cervix 13 long.

Male: Dorsal shield 275 long, 178 wide. Length of setae: j1 21, j3 36, j4 4, j5 4, j6 5, J2 5, J5 5, z4 9, z5 4, Z1 5, Z4 80, Z5 180, s2 7, s4 63, S2 7, S4 5, S5 5, r29, R1 5.

Ventri-anal shield 98 long, fused with peritremal shields, with four pairs of pores and four pairs of pre-anals. VL1 45 long.

Length of macrosetae on legs: on genu IV 77, tibia IV 54 , basitarsus IV 63 , genu III 36 , tibia III 30 , genu II 29 , genu I 32.

Length of both digits of chelicera 18. Fixed digit with one subapical tooth and eight (or seven) in a row. Movable digit with one tooth; spermatophoral process as in fig. 38, major portion 13 long, branch 5 .

Etymology. -

Boina is called the western lowland region on both sides of the Betsiboka River.

\section{Amblyseius (Amblyseius) tamatavensis}

Blommers, 1974

Amblyseius (Amblyseius) tamatavensis Blommers, 1974a: 144, figs. 6-12.

Material. - Nine $q \propto$ and nine $\delta \delta$ (M 22-2k series) from a mass rearing starting with specimens collected on several plants (Phaseolus sp., Papilionaceae; Leonotis sp., Labiatae, and Ipomoea sp., Convolvulaceae) near Katsepy, Bombetoka Bay opposite Majunga, 27.IV.1972.

Diagnosis. - These specimens are similar to the type series from Tamatave.

\section{Amblyseius (Amblyseius) deleoni \\ Muma \& Denmark, 1970}

Amblyseius (Amblyseius) largoensis; Muma, 1961 (nec largoensis Muma, 1955); Schuster \& Pritchard, 1963: 237, fig. 26; Muma, 1964: 22; Van der Merwe, 1968: 135, figs. 309-315. Amblyseius deleoni Muma \& Denmark, 1970: 68, figs. 242-246.

Material. - Two $\% \circ$ (T 3 series) collected from Hibiscus rosa-sinensis (Malvaceae), 29.VII.1971; ten $\$$ (T 6 series) from Barleria sp. (Acanthaceae) and three $\$$ ( $T 7$ series) from Fraxinus berlandieriana (Oleaceae), both on 16.IX.1971; twelve $\& \&$ (T 9 series) from Ageratum conyzoides (Compositae) on 17.IX.1971. All these specimens were collected in the zoological garden of the O.R.S.T.O.M. centre in TananariveTsimbazaza, at $1250 \mathrm{~m}$ altitude.

Diagnosis. - According to Muma \& Denmark (1970) the name $A$. largoensis had been used for two different species since Muma (1961), and $A$. largoensis Muma, 1961, was consequently renamed $A$. deleoni.

I have compared the Malagasy specimens with a specimen of $A$. deleoni from Florida identified and sent to me by Dr. H. Denmark. They are very probably conspecific, while they are certainly identical to $A$. largoensis Muma, sensu Van der Merwe (1968) from South Africa.

Setal dimensions in the female: j1 34-38, j3 4045, Z4 93-105, Z5 245-275, s4 89-96; length of macrosetae: on genu IV 105-120, tibia IV 80-86, basitarsus IV 68-75; $s 4$ is nearly always slightly shorter than Z4. Z4 often faintly serrate.

We failed to observe males in the mass rearing (see below) of this species, and eggs reared singly produced reproducing females. This thelytoky was also observed by Van der Merwe (1968), but males are mentioned by Muma \& Denmark (1970). 


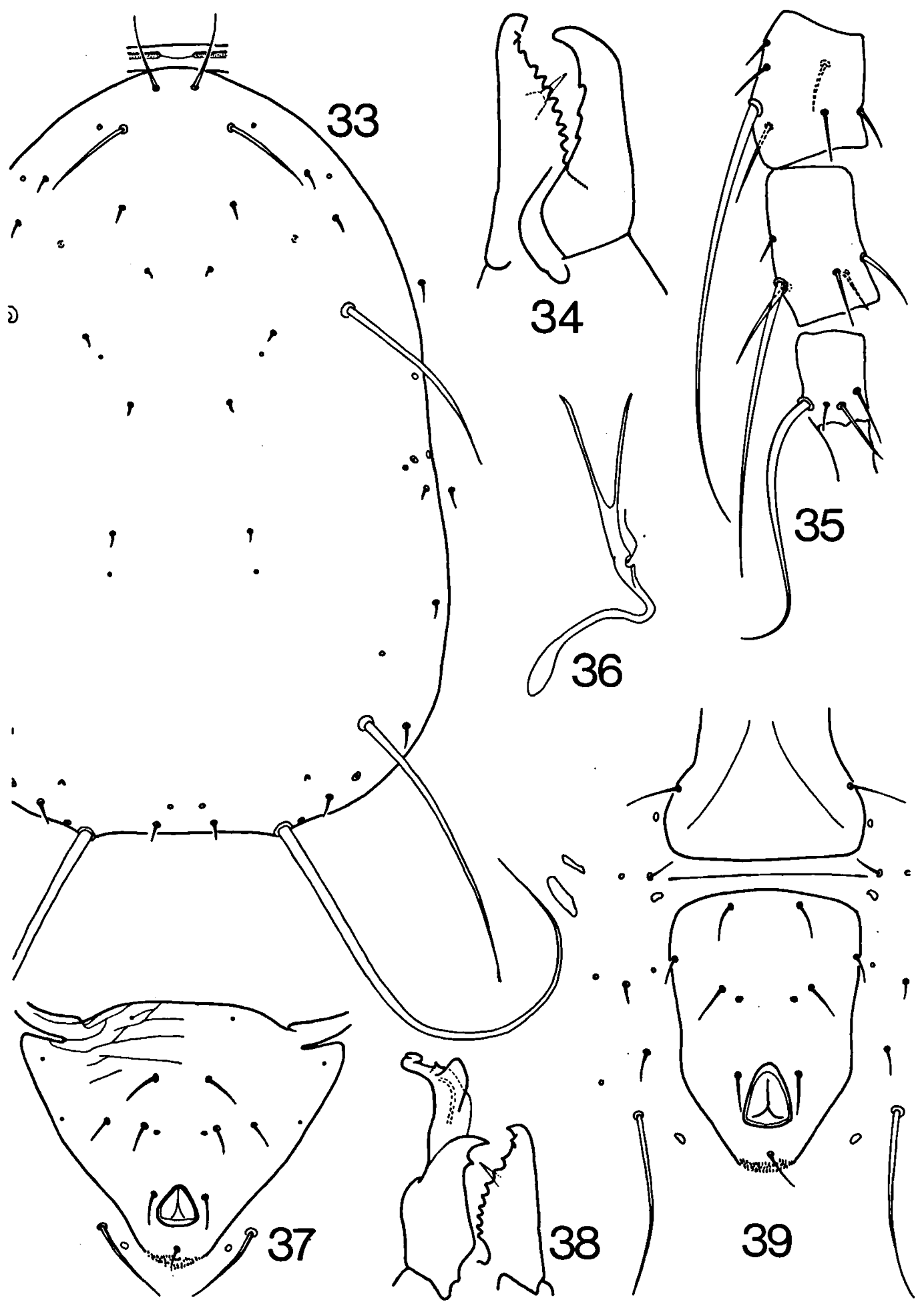

Figs. 33-39. Amblyseius boina sp. n.: 33, dorsum $q ; 34$, chelicera $q ; 35$, leg IV $q ; 36$, spermatheca $q ; 37$, ventri-anal shield $\delta ; 38$, chelicera $\delta ; 39$, genital and ventri-anal shield $q$. 
Field notes. -

A. deleoni was found in company of all sorts of small arthropods, notably the tenuipalpid mite Brevipalpus sp. (T 6, T 7, T 9), white flies (T 3, T 9), tydeid mites (T 3, T 7) and low numbers of Tetranychus neocaledonicus (T 3, T 9).

Amblyseius (Amblyseius) sakalava sp. $\mathrm{n}$.

(figs. 40-46)

Material. - Holotype $\&$ (65.3) and 5 paratypes ( $\%$ \% and 2 $\delta \delta^{\circ}$; series 65) collected on Corchorus trilocularis (Tiliaceae) in the Agricultural Garden in Tuléar, 2.IV.1971. Other paratypes: 2 \% $\%$ and $2 \delta \delta$ (52 series) from Acalypha sp. (Euphorbiaceae) and 1 \% (49.1) from Lagerstroemia indica (Lythraceae) in the same locality as the holotype, 8.III.1971. Specimens ( $3 \circ \%$ and $2 \delta \delta$, B 24 series) were also found on okra, Abelmoschus esculentus (Malvaceae) in the same garden, 25.III.1971, and on cassava (Manihot utilissima; Euphorbiaceae), 15.V.1971.

Differential diagnosis.- $A$. sakalava compares well with both $A$. largoensis (Muma, 1955) and $A$. neolargoensis Van der Merwe, 1968. It differs from the latter species in the considerably smaller size of the dorsal setae $\mathrm{s4}, \mathrm{Z4}$ and Z5. A. largoensis was never described in sufficient detail, but through the courtesy of Dr. H. Denmark I am able to compare my specimens with a specimen of $A$. largoensis from Florida; in A. sakalava all whip-like setae (also on the legs), except dorsal $\mathrm{Z5}$, are definitely longer than in the American A. largoensis, which is also different in having only $2+6$ teeth on the fixed digit of the chelicera.

The setal lengths of $A$. sakalava agree well with those described by Ehara (1959) for A. largoensis from Japan, but since the spermatheca was not described the latter might have been $A$. deleoni just as well.

\section{Description. -}

Female: Dorsal shield smooth, nearly 400 long and 270 wide; with at least fifteen pairs of pores; seventeen pairs of setae: j1 43, j3 57, j4 7, j5 4, j6 9, J2 11, J5 11, z4 9, z5 5, Z1 11, Z4 111, Z5 264, s2 13, s4 104, S2 20, S4 14, S5 12. Sublaterals on interscutal membrane; $\mathrm{r} 214$ and R1 10 long. Peritremes reaching in front of setae $\mathrm{jl}$.

Sternal shield with straight posterior border and genital shield as usual. Ventri-anal shield elongate and constricted; length 128 and maximal width 80 . Four pairs of both pores and setae on surrounding membrane; VLl 70 long.
Length tarsus IV (including basitarsus) 160. Five macrosetae on leg IV: two on genu 128 and 36 , two on tibia 104 and 27 , one on basitarsus 70 . Length of remaining macrosetae: genu III 50, tibia III 45, tarsus III 36, genu II 38 , genu I 41. Genu II with seven pairs of setae.

Fixed digit of chelicera with two subapical teeth and eight in a row. Movable digit with three tiny teeth. Length of both digits about 33 .

Spermatheca as figured. Length cervix 36.

Male: Dorsal shield 310 long and 220 wide; r2 and $R I$ on dorsal shield. Length of setae: $j 134, j 3$ 48, j4 5, j5 4, j6 7, J2 7, J5 9, z4 9, z5 5, Z1 9, Z4 80, Z5 218, s2 12, s4 86, S2 13, S4 11, S5 9, r2 14, RI 11 .

Ventri-anal shield imbricate, with three pairs of pores, fused with peritremal shields, 128 long.

Macrosetae on legs: genu IV 86 and 29, tibia IV 73 and 21 , basitarsus IV 63 , genu III 38 , tibia III 36 , basitarsus III 32 , genu II 34 , tibia II 36 , genu I 32. Length tarsus IV 130.

Fixed digit of chelicera with one subapical tooth and six teeth in a row. Movable digit with one tooth; spermatophoral process as figured, major portion 10 long, branch 5. Both digits 20 long.

Field note. -

Tetranychus neocaledonicus was always present and often quite numerous on the plants from which $A$. sakalava was recovered.

\section{Etymology. -}

The Sakalava people inhabit the entire western coast and lowlands from Ambanja in the North to Tuléar in the South.

Amblyseius (Amblyseius) trichophilus sp. n.

(figs. 47-53)

Material. - Holotype $\&$ (M 12.1) and two paratypes (M 12 series; 2 \& ) from Pueraria javanica (Papilionaceae), Ambato Boeni, 24.IV.1972: 3 paratypes (M 15 series; $2 \circ \%$ and $I \delta$ ) from Leonotis nepetaefolia (Labiatae), Tsaramandroso, Ampijoroa, on the same day as the holotype; 5 paratypes (M 28; $2 \% \%$ and $\left.3 \sigma^{\circ}\right)$ from Combretum villosum (Combretaceae), Route Nationale 4, km 491, Amboromalandy, 11.IX.1972; and 2 paratypes (M 34 series; $\&$ and $\$$ ) from Leptadenia madagascariensis (Asclepiadaceae), Tsaramandroso, Ampijoroa, 30.XI.1972. One \& (M 27k7) was collected on Urena lobata (Malvaceae), Tsaramandroso, Andranofasika, 12.IX. 1972. One $\%$ from cassava (Manihot utilissima; Euphorbiaceae), Tuléar, 18.V.1971, belongs to the same species. 


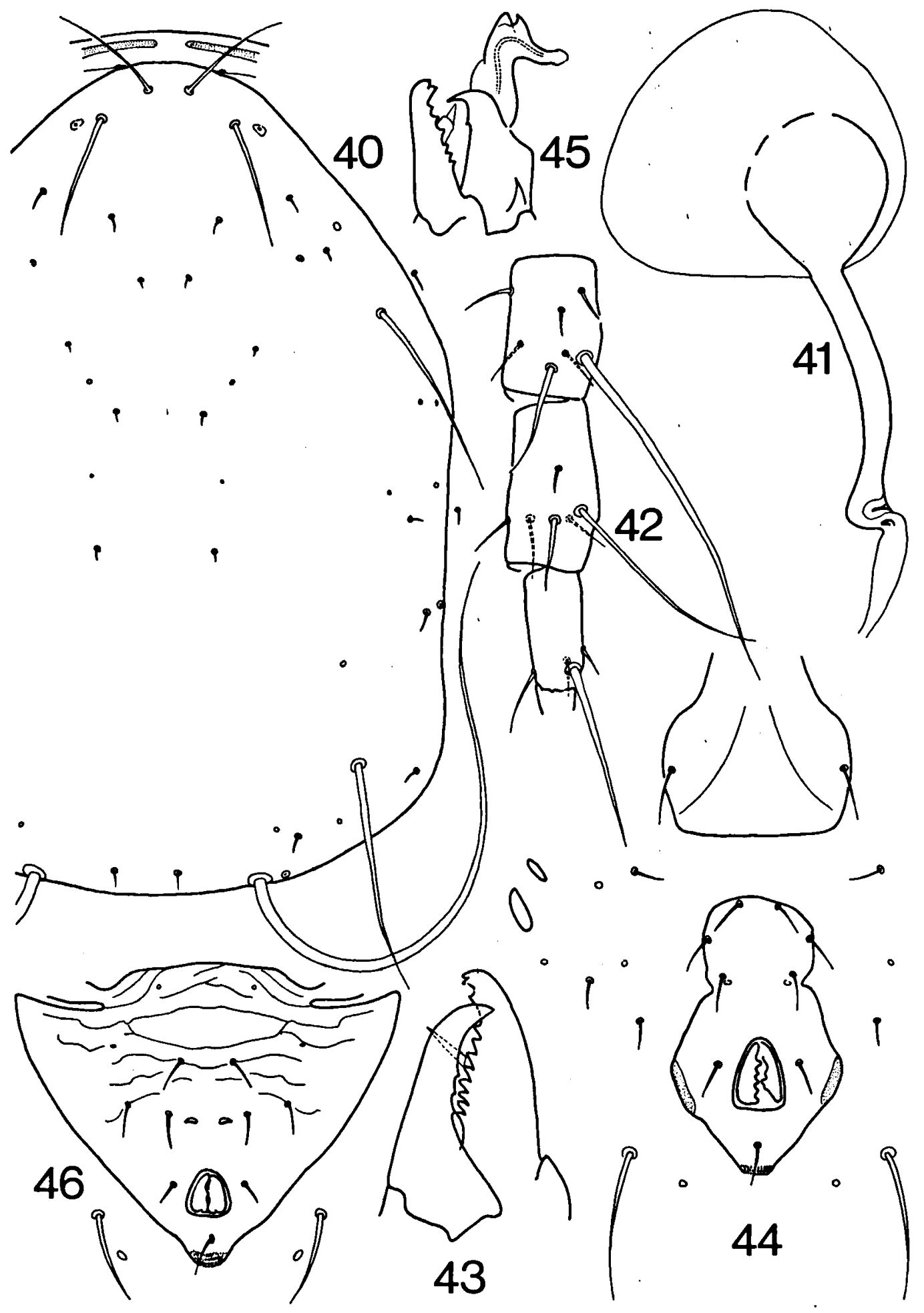

Figs. 40-46. Amblyseius sakalava sp. n.: 40, dorsum $\% ; 41$, spermatheca $\%: 42$, leg IV $\% ; 43$, chelicera $\% ; 44$, genital and ventri-anal shield $q ; 45$, chelicera $\delta ; 46$, ventri-anal shield $\delta$. 


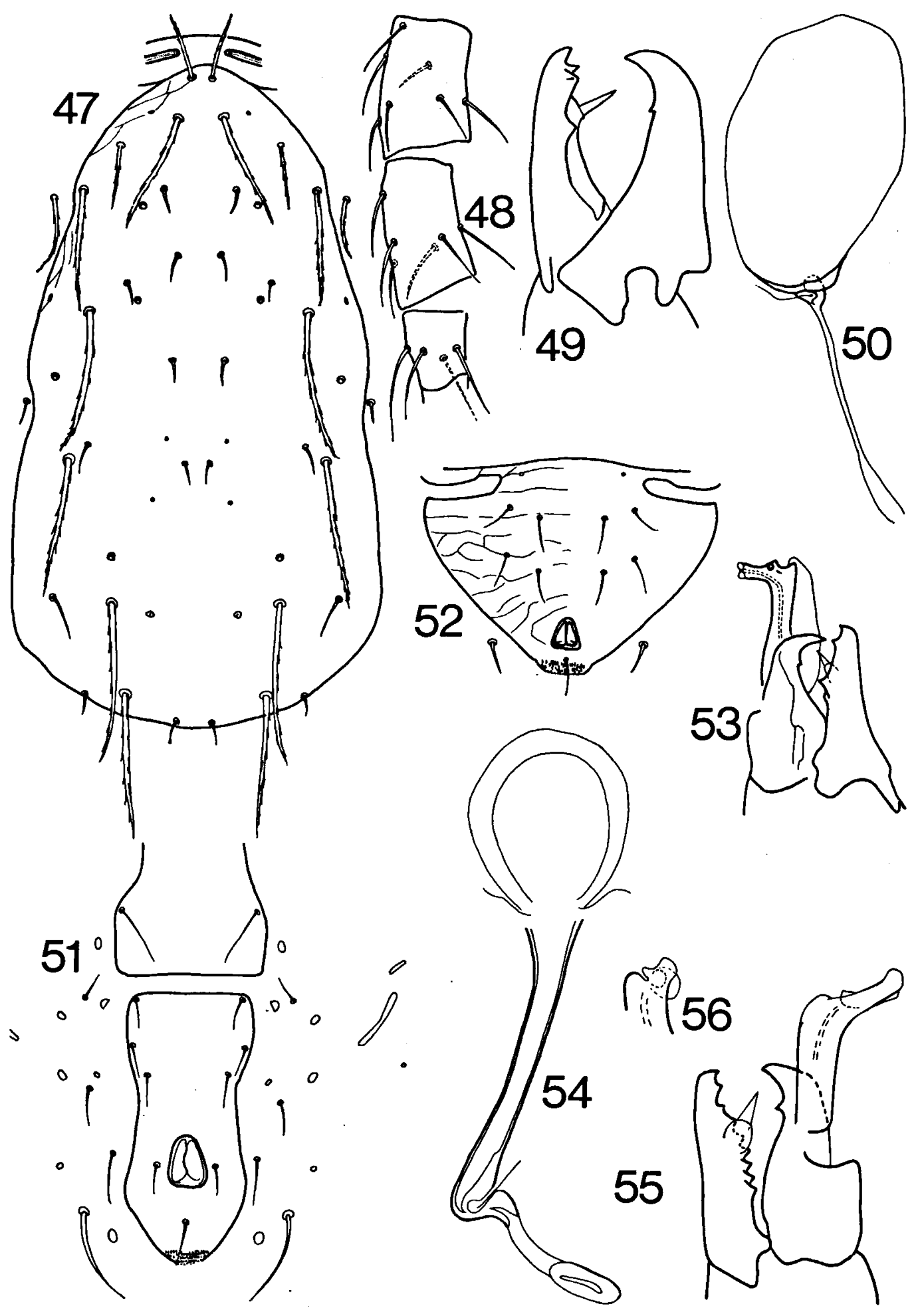

Figs. 47-53. Amblyseius trichophilus sp. n.: 47, dorsum $q ; 48$, leg IV $\% ; 49$, chelicera $q ; 50$, spermatheca $q ; 51$, genital and ventri-anal shield $q ; 52$, ventri-anal shield $\delta ; 53$, chelicera $\delta$.

Figs. 54-56. Amblyseius sundi Pritchard \& Baker, 1962: 54, spermatheca $\$ ; 55$, chelicera $\delta ; 56$, chelicera $\delta$, spermatophoral process viewed laterally. 
Differential diagnosis. $-A$. trichophilus is difficult to compare with known members of the genus. The dorsal setal pattern places it clearly within the nominate subgenus, but several other characters of this species are rare or even unique among members of this group. In fact, except for the presence of 17 pairs of dorsal setae, $A$. trichophilus resembles in almost every important feature members of the subgenus Proprioseius Chant, 1957. The possession of a number of longer serrate dorsal setae, the absence of distinct macrosetae on leg IV, the elongate form of the ventri-anal shield in the female, and the shape of the spermatheca, are characters common in Proprioseius but rare in Amblyseius.

\section{Description. -}

Female: Small-sized species. Dorsal shield 275 long and 150 wide, smooth, with at least nine pairs of pores, of which four large and conspicuous. Seventeen pairs of setae, length: j1 23, j3 4l, j4 11, j5 11, j6 11, J2 11, J5 7, z4 39, z5 7, Z1 9, Z4 57, Z5 57, s2 21, s4 54, S2 54, S4 20, S5 11. Setae j1, j3, z4, Z4, Z5, s2, s4, S2 and r2 distinctly serrate. Sublaterals r2 32 and R1 20 long. Peritremes reaching level with setae $\mathrm{jl}$.

Sternal shield with straight posterior margin. Genital shield as usual. Ventri-anal shield slender, 90 long and 50 wide; three pairs of pre-anals. Pre-anal pores absent. Surrounding membrane with six pairs of pores and four pairs of setae; VLl 38 long.

Legs without pronounced macrosetae. Genu II with 8 setae; other segments and legs normal.

Both digits of chelicera 30 long. Fixed digit with two subapical teeth and one tooth halfway. Movable digit with one tiny tooth.

Spermatheca as figured. Major duct 20 long. Atrium knob-like. Cervix platter-shaped.

Male: Dorsal shield 220 long and 125 wide. Length of setae j1 18, j3 25, j4 12, j5 14, j6 14, J2 12, J5 5, z4 36, z5 9, Z1 12, Z4 37, Z5 34, s2 20, s4 40, S2 40, S4 14, S5 11, r2 25, R1 16. Longer setae serrate as in female.

Ventri-anal shield fused with peritremal shields, 100 long, with four pairs of pre-anals; three pairs of pores; VL1 18 long.

Legs without macrosetae.

Digits chelicera 18 long. Fixed digit with two teeth, movable with one. Spermatophoral process gibbet-shaped, major portion 12 long, branch 3.
Remark. - Some specimens are substantially larger than the holotype, notably those of the $M$ 28 series. Some measurements on $\%$ M 28.1 might illustrate this: dorsal shield 310 long and 200 wide, jl 23, j3 54, z4 59, Z4 70, Z5 70, s4 64, S2 70 .

Field notes. -

It should be stressed that $A$. trichophilus was found often on plants infested with spider mites of the genus Eotetranychus, viz., E. paracybelus Gutierrez, 1967 (M 27), E. savanae Gutierrez, 1967 (M 34) and an undescribed third species (M 12).

Amblyseius (Proprioseiopsis) sundi

Pritchard \& Baker, 1962, comb. n. (figs. 54-56)

Amblyseius (Amblyseius) sundi Pritchard \& Baker, 1962: 244, figs. 24-25.

Material. - Nine $q q$ (T 10 series) collected on Citrus limon (Rutaceae) in the Agricultural Station at Nanisana, Tananarive, alt. $1250 \mathrm{~m}, 21.1 X .1971$, and three $\%$ and five $\delta \delta$ (T 10k series) from a mass rearing started with specimens of the same origin. Four $q q$ and one $\delta$ (M 6k series) originate from a rearing begun with specimens found on Ricinus communis (Euphorbiaceae) near Tsaramandroso, Ampijoroa, 24.IV.1972.

Diagnosis. - The absence of setae $\mathrm{Zl}$, which places this species clearly into the subgenus Proprioseiopsis Muma, 1961, and the extreme length of the dorsal setae $\mathrm{Z4}, \mathrm{Z5}$ and $\mathrm{s} 4$ leave little doubt about the identity of our specimens. Only minor differences in setal lengths and the existence of males distinguish them from thelytokous A. parasundi Blommers, 1974, reported previously from the East coast (Blommers, 1974a).

Female: Dorsal shield 378-427 long and 235-294 wide. Length of setae: j1 37-45, j3 45-57, Z4 196214, Z5 447-491, s4 188-200, r2 16-21. All remaining setae minute, less than 10 long.

Venter agrees with original description in shape. Ventri-anal shield 112-129 long and 75-84 wide. VLI 107-121.

Length of macrosetae: on genu IV 232-259 and 54-66, tibia IV 184-196 and 46-54, basitarsus IV 125-134 and 28-29, genu III 70-89, tibia III 59-71, basitarsus III 37-48, genu II 45-53, genu I 71-95. Two more whip-like macrosetae on both tibia and tarsus I. Length of tarsus IV (including basitarsus) 202-232. 
Both digits of chelicera about 40 long. Fixed digit with two subapical teeth and 9-11 in a row. Movable digit with three teeth.

Spermatheca with cervix 36-38 long.

Male: Dorsal shield $298 \times 200$. Length of setae: j1 30, j3 47, Z4 143, Z5 364, s4 136. Venter as usual. Ventri-anal shield fused with peritremal shields, 120 long. Macrosetae on legs: genu IV 160 and 40, tibia IV 125 and 40, basitarsus IV 98 and 20 , genu III 55 , tibia III 46 , tarsus III 32 , genu II 38 and genu I 55.

Chelicera as figured. Length digits 22. Major portion of spermatophoral process 14 , branch 9 .

\section{Field notes. -}

Some Tetranychus neocaledonicus and Brevipalpus sp. were observed on the lemon trees on which this species was collected. Ricinus communis in Ampijoroa contained rather large numbers of the same spider mite.

Amblyseius (Proprioseiopsis) tulearensis sp. $\mathrm{n}$.

(figs. 57-61)

Material. - Holotype $Q$ (B 27.3) and 6 paratypes (series 58 and B 27; all $\%$ ) from Corchorus trilocularis (Tiliaceae), botanical garden, Agricultural Station, Tuléar, 2.IV.1971.

Differential diagnosis. $-A$. tulearensis belongs to the group of species within the subgenus Proprioseiopsis Muma, 1961, in which only setae J2, and not $\mathrm{Zl}$, are absent, and genu II bears eigth setae. Unfortunately, the latter character has not been considered by a majority of workers, and was never mentioned for American A. asetus (Chant, 1959) (Schuster \& Pritchard, 1963; Muma \& Denmark, 1970), the descriptions of which fit $A$. tulearensis rather well. $A$. asetus (Chant, sensu Schuster, 1966) from the Galápagos has genu II with eight setae, but differs considerably from the original description. Therefore, I prefer to consider $A$. tulearensis a new species, which resembles $A$. apheles Van der Merwe, 1968, except for minor differences in the length of some dorsal setae, and the shape of the spermatheca.

\section{Description. -}

Female: Alive brownish red, scutal parts stay yellowish in cleared and mounted specimens. Dorsal shield smooth, not exceptionally sclerotized, 340 long and 230 wide, with at least nineteen pairs of pores. Sixteen pairs of setae (pair J2 lacking); length: j1 20, j3 27, j4 3, j5 4, j6 4, J5 7, z4 9, z5 4, Z1 9, Z4 60, Z5 104, s2 13, s4 $54, S 29, S 49, S 59$. Sublaterals $r 2$ and $R 1$ both 12 long. Peritremes reaching in front of setae jl.

Sternal shield with straight posterior margin. Genital shield as usual. Ventri-anal shield 115 long and 90 wide, mildly imbricated, with three pairs of pre-anals. Surrounding membrane with three pairs of pores and four pairs of setae; VL1 62 long.

Tarsus IV 114 long. Length of macrosetae: on genu IV 48, tibia IV 30 , basitarsus IV 61 , genu III 20, genu II 20. Genu II with eight setae (VIII-type according to Van der Merwe, 1968).

Both digits of chelicera 28 long. Fixed digit with two subapical teeth and seven in row. Movable digit with a single tiny tooth.

Major duct spermatheca 21 long, constricted in the middle; atrium small; cervix caliciform, 10 in diameter.

Male: Unknown.

Field note. -

This species was found in association with Tetranychus neocaledonicus.

\section{Amblyseius (Proprioseiopsis) peltatus}

Van der Merwe, 1968, comb. n. (figs. 62-64)

Amblyseius (Amblyseius) peltatus Van der Merwe, 1968: 119, figs. 259-264.

Material. - One \& (M 10.10) collected on Urena lobata (Malvaceae) near Ambato Boeni (Majunga province) on 24.IV.1972.

Diagnosis. - The specimen agrees with the original description of $A$. peltatus. This species should be placed in the subgenus Proprioseiopsis Muma, 1961, since the setal pair J2 is absent.

Female: Dorsal shield brownish in preparation, smooth, 320 long and 230 wide. Length of the longer setae: j1 32, j3 61, z4 25, Z4 100, Z5 110, s2 30, s4 100, S2 21.

Width of both the genital and ventri-anal shield 102; length of the latter 93. VL1 77 long. Macrosetae on legs: on genu IV 50, tibia IV 36, and basitarsus IV 86, on genu III 32 long. Genu II with seven setae. 


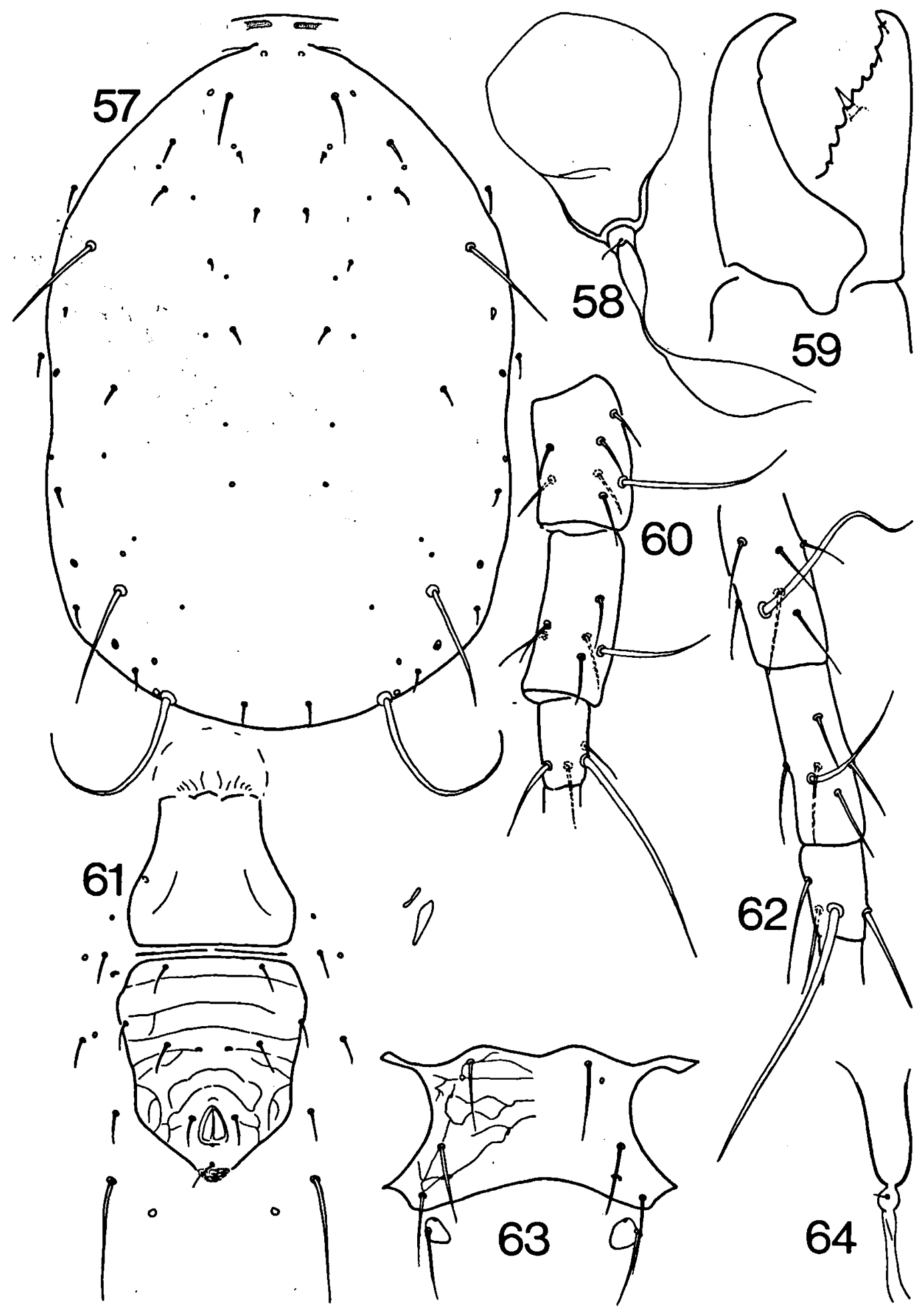

Figs. 57-61. Amblyseius tulearensis sp. n.: 57, dorsum $\% ; 58$, spermatheca $\% ; 59$, chelicera $\%$; 60 , leg IV $\% ; 61$, genital and ventri-anal shield $\%$.

Figs. 62-64. Amblyseius peltatus Van der Merwe, 1968: 62, leg IV $\% ; 63$, sternal shield $\% ; 64$, spermatheca $\%$. 
Remark. - It should be noted that $A$. peltatus resembles so much $A$. rosellus comb. $\mathrm{n}$. (Chant, 1959) from the Caribbean area, as to be a synonym of it. Having not seen the type of either, I prefer to determine the Malagasy specimen the same as the more extensively described African species.

\section{BIOLOGY}

The main purpose of our study in Madagascar was to search for phytoseiid mites as control agents for noxious tetranychids on local crops. At the time of our arrival, only a single species of Phytoseiidae was described from the island (Chazeau, 1970) and our first goal was to undertake a faunal inventory. This was combined, from the beginning, with trials to determine if the collected mites could be reared on detached leaf cultures with spider mites as food.

To this purpose, every sample collected in the field was split into two parts. A number of specimens were preserved immediately for identification. The majority, however, was used for rearing experiments. Because it is extremely difficult to recognize different phytoseiids while alive, some (negative) results could have been lost. It is possible that some species not able to live under the conditions of our rearing methods were lost and consequently not preserved.

We have made collections in four provinces: Tamatave, Tananarive, Majunga and Tuléar. The survey in the region of Tamatave concerned especially the spider mites and their predators on citrus and other fruit trees, the results of which have been published elsewhere (Blommers, 1974a; Blommers \& Gutierrez, 1975).

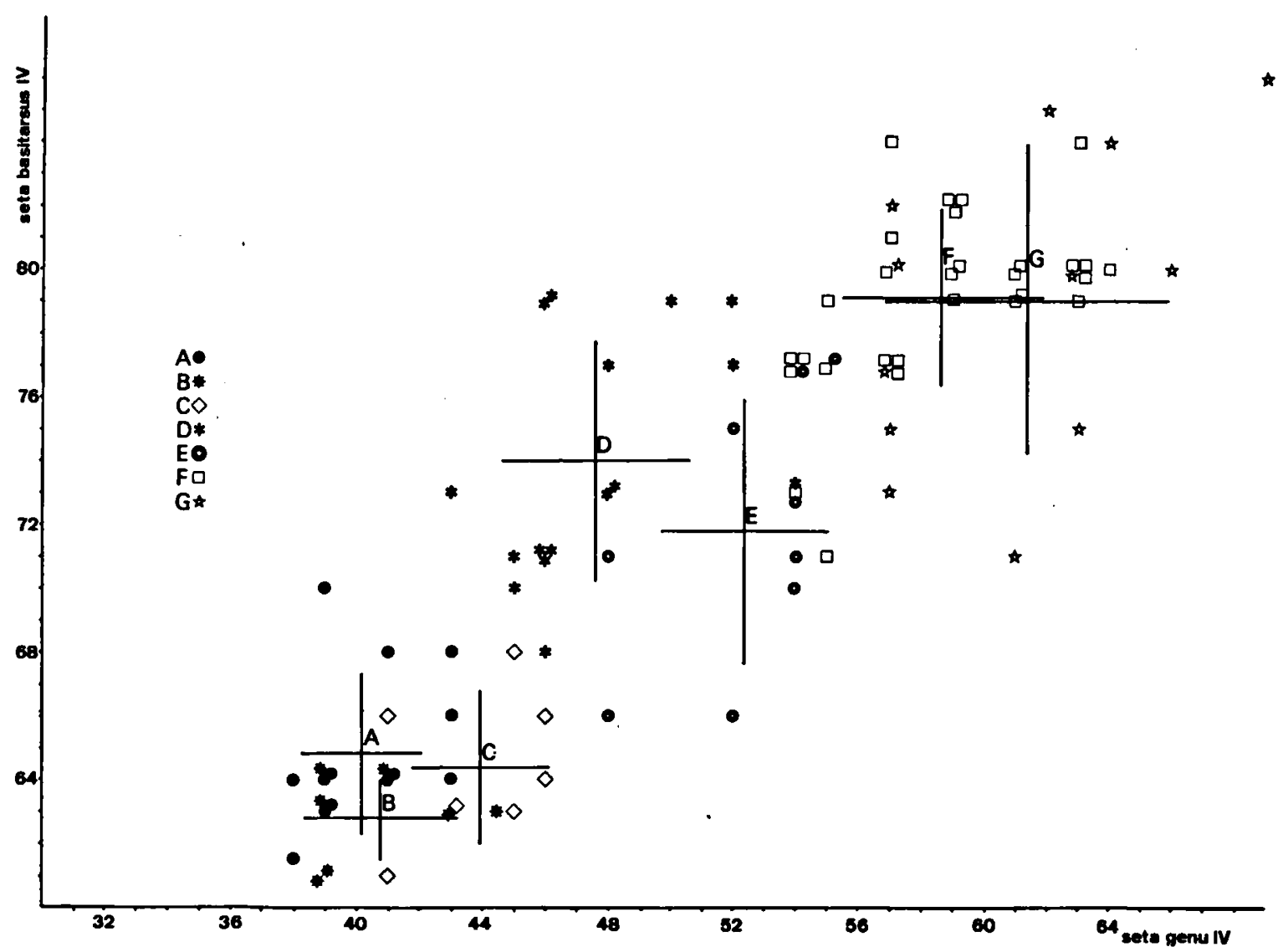

Fig. 65. Length (individual observations, mean and standard deviation) of the longest macrosetae on leg IV of the female in the Amblyseius rotundus-brevipes group: A. brevipes: A, Tuléar; B, Ambato-Boeni region; C, Tamatave; D, Tananarive.

A. rotundus: E, Ambato-Boeni region; F, Tuléar; G, Majunga-Katsepy. (See also table I.) 
Further, we have been concentrating mainly on Tetranychus neocaledonicus André, 1933, as prey species, since it is by far the most important spider mite on the island (Gutierrez, 1974).

\section{Tuléar}

Phytoseiid mites collected in the field were offered Tetranychus neocaledonicus as food alone, on detached leaves of either cotton, bean or cassava. This proved to be a quite rigorous way of screening, as only three species survived: Amblyseius masiaka and $A$. vazimba Blommers \& Chazeau, 1974 (cf. Blommers, 1974b) and $A$. bibens (cf. Blommers \& Van Etten, 1975). Other species, notably Amblyseius rotundus, A. brevipes, A. sakalava, Paraphytoseius multidentatus, Phytoseius onilahy and several Typhlodromus species, which were encountered and tested more than once, appeared unable to live with the spider mite as food exclusively.

An exception might be Amblyseius tulearensis which was found only once in low numbers, and could be maintained for a few months. Probably, inbreeding was the major reason for its extinction. However, its rareness indicates that this species can only be of minor importance with respect to spider mite regulation.

In the same region, another spider mite, Eutetranychus eliei Gutierrez \& Helle, 1971, is very common on citrus. No phytoseiids were found in evident association with it.

Nearly all our observations and collections concern the centre and immediate environment of the city of Tuléar, an area which is irrigated. Phytoseiid mites proved to be extremely rare on the sclerophyllous vegetation on the eastern limestone plateau and in the dunes near the coast, although a wide variety of spider mites occurs there (Gutierrez, pers. comm.).

\section{Majunga}

- The western coastal area. Our survey was limited to a few days visit to Katsepy, opposite Majunga on the mouth of the Betsiboka River. The dune vegetation there is more open than near Tuléar (cattle grazing), though the precipitation is about five fold (1.5 $\mathrm{m}$ instead of 0.3 annually).

Two species were found there: Amblyseius rotundus and Typhlodromus cf. gutierrezi-chazeaui, both in rather large numbers on different sorts of shrub. Several species of phytophagous mites were observed together with them, notably Tetranychus neocaledonicus, Eotetranychus savanae Gutierrez, 1967, Eutetranychus sambiranensis Gutierrez \& Helle, 1971, Oligonychus occidentalis Gutierrez, 1969, plus two unknown species of both the latter genera, Raoiella indica Hirst, 1924 and unidentified Tarsonemidae.

Amblyseius masiaka, A. tamatavensis and Typhlodromus contiguus were collected simultaneously on adventive sweet potato and bean plants in a patch of degraded dune forest on the road to Mitsinjo, in association with Tetranychus neocaledonicus.

- The western lowlands. A few short visits were made to the cotton growing area near Ambato Boeni and to the outskirts of the deciduous Ankarafantsika forest near Ampijoroa.

On all these trips, collected specimens were preserved partly in the field, while the remainder with the plant pieces harbouring them were put into plastic bags and transported to the laboratory in Tananarive. There, the material was sorted and mass rearings were started of as many as possible species by providing the phytoseiid mites on detached bean leaves with not only Tetranychus neocaledonicus but also pollen (Aloe chabaudii: Liliaceae) and beehoney. It appeared possible to rear the following species on this food: Amblyseius rotundus (M 9, M 16), A. brevipes (M 17), A. sundi (M 6), A. masiaka, A. tamatavensis and Typhlodromus contiguus (all M 22), Phytoseius betsiboka (M 30) and Typhlodromus cf. gutierrezichazeaui (M 9, M 16). Amblyseius trichophilus (M 27) and another strain of $A$. rotundus (M 11) could not be maintained in this way.

After we had established rearings of sufficient size, we experimented to determine if the animals could live with tetranychid mites exclusively, or with some other food substances. Apart from Amblyseius masiaka, which thrives well with spider mites as food (Blommers, 1974b) only one other species was capable to do so: $A$. sundi. However, it did much better if honey was supplied additionally, like we have observed previously with Amblyseius vazimba (Blommers, 1974b). All other species seemed less disposed to prey on Tetranychus neocaledonicus. If pollen was withheld, the egg production dropped gradually and none or a few juveniles became adult, as is the case for Amblyseius rotundus, $A$. brevipes, $A$. 
tamatavensis and Typhlodromus contiguus. On the contrary, all four species did well if fed with pollen exclusively, although some cannibalism occurred. Phytoseius betsiboka and the Typhlodromus species fed exclusively on the pollen, even in the presence of spider mites.

We also wanted to ascertain if some of these species would prey on Oligonychus coffeae (Nietner, 1861), a spider mite which might become noxious on some perennial crops (cf. Blommers \& Gutierrez, 1975). This spider mite was offered on detached leaves of Ricinus communis, to the exclusion of other food. A clear difference was noted between related Amblyseius rotundus and $A$. brevipes. Females of the former species, of which both strains were tested, accepted this prey readily and continued egg laying, while the latter species did not eat and succumbed. Juveniles of $A$. rotundus are annoyed considerably by the webbing of this prey at large densities, but since we have observed them to occur together on frangipani (M 11), a predator/prey relation might exist.

Amblyseius masiaka accepts Oligonychus coffeae well as prey, as do A. tamatavensis and Typhlodromus contiguus to a lesser degree.

\section{Tananarive}

Although Tetranychus neocaledonicus is also common on all sorts of plants, wild or cultivated, in the central highlands of Madagascar, we have never found any phytoseiid there clearly associated with it, excepted Amblyseius bibens (T 25) one time. Rearing experiments, too, never yielded a clear indication to this effect. The following species could be reared on a diet of Tetranychus neocaledonicus and pollen: Phytoseius amba, Iphiseius degenerans, Amblyseius hima (T 1, T 5), $A$. brevipes (T 8), A. deleoni (T 9) and A. sundi (T 10). Only $A$. sundi could be maintained on the spider mite alone. Oligonychus coffeae was not suitable for Phytoseius crinitus (T 19).

Of the species from this region, Iphiseius degenerans was studied in some detail. This unmistakable, large, wine-red species was encountered only at Tananarive. Since it is recorded from several localities in the Mediterranean (Chant, 1959b) and from high altitude in Central Africa (Pritchard \& Baker, 1962), one might assume that its distribution inside Madagascar is restricted to the central high plateau. It was found always roaming solitary in shrubs and trees, including grapevine and figs, but never in the company of spider mites. Nevertheless, it can be reared easily with Tetranychus neocaledonicus together with the pollen of Bauhinia sp. (Caesalpinaceae) or Aloe chabaudii as food. Some life history data were determined on this alimentary regime.

The duration of the juvenile development (from egg till deutonymph) takes 7.3 days at $23 \pm$ $2^{\circ} \mathrm{C}$ and $55 \pm 5 \%$ r.h.; the pre-oviposition period lasts less than three days under the same conditions (J. Chazeau, pers. comm.). The oviposition rate equals about $1.5 \mathrm{eggs} / \mathrm{female} /$ day for the first three weeks of the oviposition period at $20 \pm 1^{\circ} \mathrm{C}$ and $60 \pm 10 \%$ r.h.; the entire egg-laying period takes more than 50 days, in which a female lays about 60 eggs. Tetranychus neocaledonicus alone is insufficient food to maintain a population of this predacious mite. The juvenile development stops completely and, eventually, the young die. Also, the egg production of the young females drops drastically, in 5 days to 0.5 eggs/day at $25^{\circ} \mathrm{C}$.

While the observations so far mentioned indicate that Iphiseius degenerans is incapable of controlling Tetranychus neocaledonicus in the field, another spider mite, Oligonychus coffeae, is more susceptible to attack by this predator. This species lives on the same plants from which $I$. degenerans is recorded: notably grapevine, figs, tea etc., and occurs at times in considerable number on commercially treated plantings of the first host in the surroundings of Tananarive. The predacious mite thrives better on $O$. coffeae without pollen (on leaf arenas of Ricinus com. munis) than on any other diet tried. Predation is rather elevated: young female predators kill over ten $O$. coffeae females/day and deposit 2-3 eggs at $22 \pm 1^{\circ} \mathrm{C}$. With Tetranychus neocaledonicus plus pollen, predation drops to less than one female/ day; if pollen is withheld, the predation rises initially to approximately seven prey females in the first 24 hours, but drops thereafter in accordance with the egg production (see above).

Our results agree roughly with those of Hessein (1967) on the same predator (from Egypt) with Tetranychus pacificus McGregor, 1919, Oligonychus punicae (Hirst, 1926) and Panonychus citri (McGregor, 1916). However, none of these prey species seem to be optimal food. Addition of Hymenocyclus pollen always improved the survival of the juveniles. 
An experiment using two potted Ricinus communis plants in the laboratory showed that Iphiseius degenerans is capable of exterminating Oligonychus coffeae also outside the confinement of a detached leaf culture.

\section{ACKNOWLEDGEMENTS}

This study was conducted as a part of project GUA-4 of the Netherlands' University Foundation for International Cooperation (NUFFIC), in collaboration with the ORSTOM centre (Office de la Recherche Scientifique et Technique Outre-Mer) in Tananarive. The author is extremely grateful to Dr. Jean Gutierrez and Mr. Jean Chazeau who have helped him full-heartedly and in every way with his research in Madagascar, and to Mr. Rasoloson Jacques who, with his quiet precision, took care of the mass rearings.

\section{REFERENCES}

Athias-Henriot, C., 1957. Phytoseiidae et Aceosejidae (Acarina, Gamasina) d'Algérie. Bull. Soc. Hist. nat. Afr. N., 48: 319-352.

—, 1966. Contribution à l'étude des Amblyseius paléarctiques (Acariens Anactinotriches, Phytoseiidae). Bull. scient. Bourgogne, 24: 181-230.

Berlese, A., 1889. Acari, Myriapoda, et Scorpiones hucusque in Italia reperta, 54 (9): [1-3] (Tipografia del seminario, Padova).

Blommers, L., 1973. Five new species of phytoseiid mites (Acarina: Mesostigmata) from Southwest Madagascar. Bull. zool. Mus. Univ. Amsterdam, 3: 109-117.

-, 1974a. Species of the genus Amblyseius Berlese, 1914, from Tamatave, East Madagascar. Bull. zool. Mus. Univ. Amsterdam, 3: 143-155.

-, 1974b. Preliminary studies on two predators (Acarina: Phytoseiidae) of the spider mite Tetranychus neocaledonicus André (Acarina: Tetranychidae). Z. angew. Ent., 75: 315-321.

Blommers, L. \& J. Chazeau, 1974. Two new species of predator mites of the genus Amblyseius Berlese (Acarina: Phytoseiidae) from Madagascar. Z. angew. Ent., 75: 308-315.

Blommers, L. \& J. van EtTen, 1975. Amblyseius bibens (Acarina: Phytoseiidae), a predator of spider mites (Tetranychidae) in Madagascar. Entomologia exp. appl., 18: 329-336.

Blommers, L. \& J. GutierRez, 1975. Les tétranyques vivant sur agrumes et avocatiers dans la région de Tamatave (Madagascar-est) et quelques-uns de leurs prédateurs. Fruits, 30: 191-200.

Chant, D. A., 1957. Descriptions of two new phytoseiid genera (Acarina: Phytoseiidae), with a note on the genus Phytoseius Ribaga, 1902. Can. Ent., 89: 357-363.

-, 1959a. Description of a new species of Typhlodromus (A. carina: Phytoseiidae), from Eastern Asia. Can. Ent., 91: 29-31.

-, 1959b. Phytoseiid mites (Acarina: Phytoseiidae). Part I. Bionomics of seven species of Southeastern England. Part
II. A taxonomic review of the family Phytoseiidae, with descriptions of 38 new species. Can. Ent., 91 (suppl. 12): $1-166$.

Chazeau, J., 1970. Typhlodromus scytinus n. sp., nouveau phytoséiide de Madagascar (Acariens, Gamasides, Phytoseiidae). Cah. Off. Rech. Sci. Tech. Outre-Mer, Sér. Biol., $12: 3-14$.

Corpuz, L. A. \& L. Rimando, 1966. Philippine Amblyseiinae (Phytoseiidac: Acarina). Philipp. Agric., 50: 114-136.

Denmark, H. A., 1966. Revision of the genus Phytoseius Ribaga, 1904 (Acarina: Phytoseiidae). Fla. Dept. Agric. Div. Plant Ind. Bull., 6: 1-105.

EharA, S., 1959. Some predatory mites of the genera Typhlodromus and Amblyseius from Japan (Phytoseiidae). Acarologia, 1: 285-295.

-, 1967. Phytoseiid mites from Okinawa Island (Acarina: Mesostigmata). Mushi, 40: 67-82.

- , 1972. Some phytoseiid mites from Japan, with description of thirteen new species (Acarina: Mesostigmata). Mushi, 46: $137-173$.

ÉHARA, S. \& L. H. Y. LeE, 1971. Mites associated with plants in Hong Kong. J. Fac. Educ. Tottori Univ. (Nat. Sci.), 22: $61-78$.

Evans, G. O., 1954. The genus Iphiseius Berl. (Acarina: Laelaptidae). Proc. zool. Soc. Lond., 124: 517-526.

Evans, G. O. \& D. Macfarlane, 1961. A new mite of the genus Phytoseius Ribaga (Acari: Mesostigmata). Ann. Mag. nat. Hist., (13) 4: 587-588.

GuptA, S. K., 1969. Three new species of the genus Phytoseius (Acarina: Phytoseiidae) from India. Israel J. agric. Res., 19: 115-120.

GutierreZ, J., 1974. Étude biologique et écologique de Tetranychus neocaledonicus (Acariens, Tetranychidae): 1-145 (Thèse de Doctorat d'Etat, Univ. Paris-Sud, France).

Hessein, N. A., 1967. Studies on the bionomics of the predacious mite Iphiseius degenerans (Berl.) (Acarina: Phytoseiidae): 1-102 (Ph. D. Thesis, Univ. Calif., Riverside, USA).

Leon, D. DE, 1965. Phytoseiid mites from Puerto Rico with descriptions of new species (Acarina: Mesostigmata). Fla. Ent., 48: $121-131$.

Lindquist, E. E. \& G. O. Evans, 1965. Taxonomic concepts in the Ascidae with a modified setal nomenclature for the idiosoma of the Gamasina (Acarina: Mesostigmata). Mem. ent. Soc. Can., 47: 1-66.

Merwe, G. G. van der, 1965. South African Phytoseiidae (Acarina). I. Nine new species of the genus Amblyseius Berlese. J. ent. Soc. sth. Afr., 28: 57-76.

-, 1968. A taxonomic study of the family Phytoseiidae (Acari) in South Africa, with contributions to the biology of two species. Entomology Mem. Dep. agric. tech. Serv. repub. S. Afr., 18: [i-iv], 1-198.

MumA, M. H., 1955. Phytoseiidae (Acarina) associated with citrus in Florida. Ann. ent. Soc. Am., 48: 262-272.

-, 1961. Subfamilies, genera and species of Phytoseiidae (Acarina: Mesostigmata). Bull. Fla. State Mus., 5: 267-302.

-, 1964. Annotated list and keys to Phytoseiidae (Acarina: Mesostigmata) associated with Florida citrus. Fla. agric. Exp. Stn. tech. Bull., 685: $1-42$.

-, 1967. New Phytoseiidae (Acarina: Mesostigmata) from southern Asia. Fla. Ent., 50: 267-280.

Muma, M. H. \& H. A. Denmark, 1968. Some generic descrip- 
tions and name changes in the family Phytoseiidae (Acarina: Mesostigmata). Fla. Ent., 51: 229-240.

— \& - 1970. Phytoseiidae of Florida: 1-150 (Fla. Dept. Agric. Cons. Serv., Gainesville, Fla., U.S.A.).

Narayanan, E. S., R. B. Kaur \& S. Ghai, 1960. Importance of some taxonomic characters in the family Phytoseiidae Berl. 1916 (predatory mites) with new records and descriptions of species. Proc. nat. Inst. Sci. India, (B) 26: 384-394.

NesBitt, H. H. J., 1951. A taxonomic study of the Phytoseiinae (Family Laelaptidae) predaceous upon Tetranychidae of economic importance. Zool. Verh. Leiden, 12: 1-64.

Pritchari), A. E. \& E. W. Baker, 1962. Mites of the family Phytoseiidae from Central Africa, with remarks on the genera of the world. Hilgardia, 33: 205-309.

Ribaga, C., 1904. Gamasidi planticoli. Riv. Patol. veg., 10: $175-178$.

SCHUSTER, R. O., 1966. Phytoseiidae of the Galápagos Islands (Acarina: Mesostigmata). Pacif. Insects, 8: 319-339.

Schuster, R. O. \& A. E. Pritchard, 1963. Phytoseiid mites of California. Hilgardia, 34: 19-285.

SwIRSKI, E. \& S. AmItaI, 1966. Descriptions of the males of four phytoseiid mites (Acarina) from Hong Kong. Israel J. agric. Res., 16: 11-18.

SWIRSKI, E. \& R. SHeChteR, 1961. Some phytoseiid mites (Acarina: Phytoseiidae) of Hong Kong, with a description of a new genus and seven new species. Israel J. agric. Res., 11: 97-117. 